NBER WORKING PAPER SERIES

\title{
THE EVOLUTION OF THE MEXICAN-BORN WORKFORCE IN THE UNITED STATES
}

\author{
George J. Borjas \\ Lawrence F. Katz \\ Working Paper 11281 \\ http://www.nber.org/papers/w11281
}
NATIONAL BUREAU OF ECONOMIC RESEARCH
1050 Massachusetts Avenue
Cambridge, MA 02138
April 2005

The views expressed herein are those of the author(s) and do not necessarily reflect the views of the National Bureau of Economic Research.

(C)2005 by George J. Borjas and Lawrence F. Katz. All rights reserved. Short sections of text, not to exceed two paragraphs, may be quoted without explicit permission provided that full credit, including $@$ notice, is given to the source. 
The Evolution of the Mexican-Born Workforce in the United States

George J. Borjas and Lawrence F. Katz

NBER Working Paper No. 11281

April 2005

JEL No. J1, J6

\begin{abstract}
This paper examines the evolution of the Mexican-born workforce in the United States using data drawn from the decennial U.S. Census throughout the entire 20th century. It is well known that there has been a rapid rise in Mexican immigration to the United States in recent years. Interestingly, the share of Mexican immigrants in the U.S. workforce declined steadily beginning in the 1920s before beginning to rise in the 1960s. It was not until 1980 that the relative number of Mexican immigrants in the U.S. workforce was at the 1920 level. The paper examines the trends in the relative skills and economic performance of Mexican immigrants, and contrasts this evolution with that experienced by other immigrants arriving in the United States during the period. The paper also examines the costs and benefits of this influx by examining how the Mexican influx has altered economic opportunities in the most affected labor markets and by discussing how the relative prices of goods and services produced by Mexican immigrants may have changed over time.
\end{abstract}

George J. Borjas

Kennedy School of Government

Harvard University

79 JFK Street

Cambridge, MA 02138

and NBER

gborjas@harvard.edu

Lawrence F. Katz

NBER

1050 Massachusetts Avenue

Cambridge, MA 02138

and Harvard University

lkatz@harvard.edu 


\section{THE EVOLUTION OF THE MEXICAN-BORN WORKFORCE IN THE UNITED STATES}

\section{George J. Borjas and Lawrence F. Katz*}

\section{Introduction}

The population of Mexican-born persons residing in the United States has increased at an unprecedented rate in recent decades. This increase can be attributed to both legal and illegal immigration. During the entire decade of the 1950s, only about 300 thousand legal Mexican immigrants entered the United States, making up 12 percent of the immigrant flow. In the 1990s, 2.2 million Mexicans entered the United States legally, making up almost 25 percent of the legal flow (U.S. Immigration and Naturalization Service, 2002). In addition, it is estimated that (as of January 2000) there were 7 million illegal aliens residing in the United States, with 4.8 million (68 percent of this stock) being of Mexican origin (U.S. Department of Commerce, 2004). As a result of the increase in the number of legal and illegal Mexican immigrants, nearly 9.2 million Mexican-born persons resided in the United States in 2000, comprising about 29.5 percent of the foreign-born population (U.S. Census Bureau, 2003).

It is instructive to place the Mexican immigrant influx of the late $20^{\text {th }}$ century in the context of earlier immigrant flows. In 1920, towards the end of the First Great Migration, the largest two national origin populations enumerated by the 1920 Census were Germans and Italians, and together these two populations comprised about 23.7 percent of the foreign-born population at the time (U.S. Bureau of the Census, 1975). From this perspective, it is clear that the Mexican-born population of the late $20^{\text {th }}$ Century is historically unprecedented, being both numerically and proportionately larger than any other immigrant influx in the past century.

\footnotetext{
* Harvard University and National Bureau of Economic Research.
} 
This paper analyzes the evolution of Mexican immigration as a component of the U.S. workforce during the $20^{\text {th }}$ Century. As a result of the rapidly increasing Mexican immigrant influx described earlier, the fraction of the workforce composed of Mexican-born workers increased rapidly after 1970. As the top panel of Figure 1 shows, only 0.4 percent of the workforce aged 18-64 in 1970 was composed of Mexican-born workers. By 2000, the Mexican immigrant share had increased to 4.0 percent. The increase is even larger in the male workforce, where 0.5 percent of working men were Mexican-born in 1970 and 5.1 percent in 2000 .

It is of interest to contrast the explosion of Mexican workers in the U.S. workforce in the late $20^{\text {th }}$ Century with the demographic trends at the beginning of the century. Although Mexican immigration was relatively small in the early 1900s, the relative number of Mexican immigrants in the U.S. workforce increased to 0.6 percent in 1920 (and continued rising until the late 1920s). The halting of European migration to the United States with the outbreak of World War I followed by Congressional action to restrict immigration combined with strong labor demand in the booms of the late 1910 s and the 1920s engendered substantial efforts by U.S. employers to recruit Mexican laborers through private labor contractors (Massey, Durand, and Malone 2002). ${ }^{1}$ Remarkably, the Mexican immigrant share went into a long steady decline after the 1920s that lasted for several decades. It was not until the1970s that the Mexican immigrant share of the workforce was at least as large as it was in the1920s!

The reasons for the declining Mexican share in the workforce are not entirely clear. ${ }^{2}$ Until 1965, there was not a numerical limitation on immigration from countries in the Western

\footnotetext{
${ }^{1}$ Mexican immigrants were exempted from the head tax and literacy test imposed on new arrivals in 1917 and from the national origin quotas of the immigration restriction acts of the $1920 \mathrm{~s}$.

2 Massey, Durand, and Malone (2002) argue that the weak U.S. labor market of the Great Depression generated more hostile attitudes of U.S. citizens towards Mexican immigrants and created political pressures leading
} 
Hemisphere. In theory, at least, legal migration from Mexico was guided by a "first-come, firstserved" approach. Potential immigrants applied for entry and local consular officials had a great deal of discretion in determining which applicants would be provided entry visas.

To ease the labor force shortage caused by World War II in the agricultural industry during the early 1940s, the bracero program was launched on August 4, 1942. This guest-worker program brought almost 5 million Mexican-born farm workers to the United States between 1942 and 1964, when it was abruptly terminated by the United States. The main reason given for the discontinuation of the program at the time was the assertion that the bracero program depressed the wages of native-born Americans in the agricultural industry (Massey and Liang, 1989; Marcell, 1994).

The latest wave of illegal immigration from Mexico began in the late 1960s, after the discontinuation of the bracero program. There is, in fact, a clear link between the end of the bracero program and the beginning of the illegal alien flow, at least as measured by the number of Mexican nationals aliens apprehended as they attempt to enter the United States illegally. The number of Mexican illegal aliens apprehended by the Border Patrol began to increase soon after the bracero program ended. In 1964, for example, the Border Patrol apprehended only 41.6 thousand Mexican illegal aliens. By 1970, apprehensions were up to 348.2 thousand annually. In 1986, about 1.7 million Mexican illegal aliens were apprehended (U.S. Immigration and Naturalization Service, various issues).

Although the discontinuation of the bracero program may help explain why illegal immigration accelerated in the 1960s and 1970s, there are several questions that remain

to several highly-publicized mass deportations of Mexican immigrants over the course of the 1930s. These changing economic incentives and immigration policies may have played a key role in stemming Mexican migration to the United States and even reducing the absolute number of Mexican working in the United States during the 1930s. 
unanswered. The wage gap between Mexico and the United States has been large for many decades, and it is far from clear that it is larger now than it was at the beginning or middle of the $20^{\text {th }}$ Century. Why then didn't we observe large flow of Mexican immigrants prior to the 1970s? It is possible, of course, that the policy changes initiated by the 1965 Amendments and subsequent legislation, which made family reunification the central goal of immigration policy, could have eased the entry of Mexicans in the United States, but, at least in theory, Mexican immigration was not greatly restricted prior to the post-1965 policy shifts? Why did so few Mexicans take advantage of it? Or were the institutional barriers placed at the consular level in Mexico so forbidding that relatively few Mexicans even bothered to apply to enter the United States?

We do not know the answers to these questions. What we do know, however, is that the Mexican immigrant population today stands out from the rest of the immigrant population in two striking ways. It is well known, of course, that there has also been a sizable increase in the number of non-Mexican immigrants admitted to the United States. Nevertheless, Mexican immigrants comprise an ever-larger fraction of the foreign-born stock of the United States (see Figure 2). Second, as we will document, Mexican immigrants tend to have demographic and socioeconomic characteristics that differ significantly not only from that of the native-born population, but from that of other immigrants as well. In general, the economic performance of Mexican immigrants lags significantly behind that of other immigrant groups and this lagging performance is, to an important extent, transmitted to future generations of native-born workers of Mexican ancestry. 
This paper differs from earlier contributions in the immigration literature by focusing specifically on the evolution of the Mexican-born workforce in the United States. ${ }^{3}$ We use data drawn from the Integrated Public Use Microdata Samples (IPUMS) of the decennial U.S. Census throughout the entire $20^{\text {th }}$ century to describe the demographic and economic evolution of this population. The paper examines the evolution of the relative skills and economic performance of Mexican immigrants, and contrasts this evolution to that experienced by other immigrants arriving in the United States during the period. The paper also examines the costs and benefits of this influx by examining how the Mexican influx has altered economic opportunities in the most affected labor markets and by discussing how the relative prices of goods and services produced by Mexican immigrants may have changed over time.

\section{Data and Key Trends}

The analysis uses data drawn from all of the available Integrated Public Use Microdata Samples (IPUMS) of the U.S. Decennial Census between 1900 and 2000. ${ }^{4}$ This long-term look at the available data helps to provide a historical account of the evolution and economic performance of Mexican immigrants in the U.S. workforce.

\footnotetext{
3 Important exceptions include Feliciano (2001), who examines the economic performance of Mexican immigrants through 1990; Camarota (2001), who attempts a cost-benefit analysis of Mexican immigration; and Trejo (2003), who studies the intergenerational mobility of Mexican-origin workers in the U.S. labor market. Broader analyses of immigrant and Hispanic labor market performance in the United States include Borjas (1985, 1995); Funkhouser and Trejo (1995); and LaLonde and Topel (1992).

${ }^{4}$ IPUMS samples are currently available for every decennial census in the $20^{\text {th }}$ century except for 1930.
} 
Throughout the analysis, a person is classified as an "immigrant" if he or she was born in a foreign country; all other workers are classified as "natives". ${ }^{5}$ Persons who are immigrants and who were born in Mexico comprise the sample of Mexican immigrants. The pre-1970 Censuses comprise (roughly) a 1 percent random sample of the population. Beginning with 1980, the data comprise a 5 percent random sample of the population. The entire available sample in each Census is used in the empirical analysis.

In each Census, the study is restricted to persons aged 18-64 who work in the civilian sector, are not enrolled in school, and do not reside in group quarters. ${ }^{6}$ When appropriate, the sampling weights reported in the IPUMS data are used in the calculations.

\section{The Geographic Sorting of Mexican Immigrants}

Table 1 begins the empirical analysis by documenting how the geographic sorting of Mexican immigrants in the United States changed over the $20^{\text {th }}$ century. The top panel of the table reports the share of the stock of Mexican immigrants (both male and female) who reside in

\footnotetext{
${ }^{5}$ Persons born abroad of American parents and persons born in a U.S. possession are also classified as natives. It is important to note that the Census data contain both legal Mexican immigrants as well as those illegal immigrants who answered the Census questionnaire.

${ }^{6}$ In the 1940-2000 samples, the study is also restricted to workers who report positive weeks worked and hours worked weekly, and positive earnings in the calendar year prior to the survey. Prior to 1980, the information on hours worked refers to hours worked last week; in the 1980-2000 Censuses, the information refers to usual hours worked weekly. In the 1960-1970 Censuses, weeks worked are reported as a categorical variable. We imputed weeks worked for each worker as follows: 6.5 weeks for 13 weeks or less, 20 for 14-26 weeks, 33 for 27-39 weeks, 43.5 for 40-47 weeks, 48.5 for 48-49 weeks, and 51 for 50-52 weeks. Similarly, in the 1960-1970 Censuses, hours worked last week are reported as a categorical variable. We imputed weekly hours worked for each worker as follows: 7.5 hours for 1-14 hours, 22 for 15-29 hours, 32 for 30-34 hours, 37 for 35-39 hours, 40 for 40 hours exactly, 44.5 for 41-48 hours, 54 for 49-59 hours, and 70 for at least 60 hours. In the 1940-1980 Censuses, the top coded annual salary is multiplied by 1.5. We calculated a wage rate for each worker by taking the ratio of annual earnings to the product of weeks worked and hours worked weekly. We restrict the analysis in each Census to workers whose calculated hourly wage rate lies between \$1 and \$250 (in 1999 dollars).
} 
a particular state at a particular point in time, while the bottom panel reports the fraction of the state's workforce that is composed of Mexican immigrants.

The top panel of Table 1 reports an important trend: a steady and substantial redistribution in Mexican immigration from Texas to California throughout much of the $20^{\text {th }}$ century. In 1900, for example, 62.5 percent of Mexican immigrants lived in Texas, and only 7.8 percent lived in California. By 1950, roughly equal numbers of Mexican immigrants lived in Texas (39.1 percent) and California (40.3 percent). By 1980, almost 60 percent of Mexican immigrants lived in California and the fraction of living in Texas had further declined to 21.2 percent. Between 1980 and 2000, however, California seemed to become a relatively less attractive destination for Mexican immigrants. By 2000, the fraction of Mexican immigrants living there had declined to 42.1 percent. Note, however, that this decline was not accompanied by an increase in the fraction choosing to reside in Texas; that share was relatively constant over the period.

Table 1 also shows that the recent decline in the relative share of Mexican immigrants who choose to live in California has been accompanied by a remarkable increase in Mexican immigration to states that had never been the recipients of large numbers of these immigrants. In 1980, for example, Mexican immigrants had, at best, a negligible presence in both North Carolina and Georgia. By 2000, however, almost 3.0 percent of the workforce in each of these states was composed of Mexican immigrants. Similarly, less than 1 percent of workers in Colorado were Mexican-born in 1980; by 2000, almost 5 percent of Colorado's workforce was Mexican-born. Although often noted in the popular press, this remarkable and sudden shift in the geographic sorting of Mexican immigrants in the United States has received little systematic 
analysis and the reasons leading to the dramatic geographic redistribution are still not well understood. ${ }^{7}$

Because there were relatively few Mexican immigrants living in the United States at the beginning of the $20^{\text {th }}$ century, it is worth noting that even though nearly two thirds of Mexican immigrants lived in Texas in 1900, only 3.4 percent of the Texas workforce was Mexican-born. By 2000, however, nearly 14.8 percent of the California workforce and 10.9 percent of the Texas workforce were Mexican-born. The relative importance of Mexican immigration as a component of the workforce of the main immigrant-receiving states, therefore, now stands now at a historic high. The growth has been most dramatic in California. In 1970, only 2.4 percent of California's workforce was Mexican-born. By 2000, this statistic had increased six-fold, to 14.8 percent.

\section{Trends in Educational Attainment and Occupation}

The skill composition of the Mexican immigrant workforce differs strikingly from that of the native workforce as well as from that of other immigrants. We begin the description of the skill composition of the various groups by comparing the trend in the educational attainment of native working men with that of Mexican immigrant men. The Census provides data on educational attainment beginning in 1940, so that this phase of the study focuses on the trends in the post-1940 period. As Table 2 shows, 67.3 percent of male native-born working men were high-school dropouts in $1940 .{ }^{8}$ This high native dropout rate was lower than that of Mexican immigrant men, where 94.6 percent had not completed high school. To provide a point of

\footnotetext{
${ }^{7}$ See Card and Lewis (2005) for an initial analysis of the geographic redistribution of Mexican immigrants during the 1990 s.

${ }^{8}$ We refer to anyone with fewer than 12 years of completed schooling as a high school dropout.
} 
reference for these statistics, the table also reports that 84.4 percent of non-Mexican immigrant working men at that time were high school dropouts. ${ }^{9}$

By 2000, the fraction of male native-born workers who are high school dropouts had fallen by almost 60 percentage points, to 8.7 percent. In contrast, the fraction of Mexican-born high school dropouts had fallen by only about 30 percentage points, to 63.0 percent. Again, as a reference point, note that the fraction of high school dropouts in the non-Mexican immigrant population had fallen by almost as much as in the native-born workforce, to 17.0 percent. As a result of these trends, the data indicate a remarkable fact: the population of male high school dropouts in the United States has become disproportionately Mexican-born. In 1940, 0.5 percent of all male high school dropouts were Mexican immigrants. Even as recently as 1980, only 4.1 percent of male high school dropouts were Mexican immigrants. By 2000, however, 26.2 percent of all male high school dropouts were Mexican born.

The growing disadvantage of Mexican immigrants at the bottom of the educational attainment distribution is matched by an equally growing disadvantage at the top of the distribution, where a fast-growing number of native workers and non-Mexican immigrants are college graduates. In 1940, there was relatively little difference in college graduation rates among the three groups; by 2000 , however, there is a wide gulf separating college graduation rates between Mexican immigrants and the other groups. In particular, 6.3 percent of native working men were college graduates in 1940, and this fraction had quadrupled to 27.4 percent by 2000. Similarly, 3.7 percent of non-Mexican immigrant men were college graduates in 1940, and this fraction had increased almost ten-fold to 36.3 percent by 2000 . In contrast, only 1.4 percent

\footnotetext{
${ }^{9}$ Information on literacy in the 1900 to 1920 censuses suggests a similar educational gap for Mexican immigrant workers in the early $20^{\text {th }}$ century. For example, the literacy rate for Mexican-born male workers was
} 
of Mexican immigrant men in 1940 were college graduates; by 2000, the college graduation remained a miniscule 3.4 percent in this group of workers.

The bottom panel of Table 2 reports the trends in the education distribution for working women. The trends are similar to those reported for the various groups of working men, though not as dramatic. For example, the high school dropout rate of native women dropped by 44 percentage points between 1940 and 2000 (from 50.6 to 6.5 percent), as compared to the almost 60 percentage point drop experienced by native men. Similarly, the high school dropout rate for Mexican immigrant women dropped by 28 percentage points (from 84.5 to 57.0 percent), as compared to the 32 percentage point drop experienced by Mexican immigrant men. These data patterns presage a systematic finding in much of our analysis: the differences exhibited by the various groups of working women mirror those exhibited among the respective groups of working men, but are less extreme. As a result of this similarity, much of the discussion that follows will focus on the trends observed in the sample of working men (even though many of the tables will report the respective statistics for working women). By focusing on the trends exhibited by working men, we can avoid the difficult conceptual and econometric issues introduced by the interpretation of skill and wage trends for working women during a period of rapidly rising female labor force participation rates.

Finally, Table 3 illustrates the changing occupational distribution of Mexican immigrants by listing the "Top Ten" occupations employing these workers. The IPUMS data recode the very different occupation codes used by the various Censuses into a single occupation categorization based on the 1950 Census definitions. We use this simplifying recoding to compare the occupation distribution of workers across Censuses. 
Not surprisingly, such low-skill occupations as laborers, farm laborers, gardeners and cooks, dominate the occupational distribution of Mexican immigrants. It is worth noting, however, that there seems to be much less occupational clustering among Mexican immigrants in the late 1900s than there was at the beginning of the century. In 1900, for example, almost twothirds of Mexican immigrant men were employed as laborers or farm laborers. In 2000, the largest concentration of Mexican immigrant men is found in operatives (not elsewhere classified), which employs "only" 15.5 percent of the workers.

\section{Trends in the Relative Wage}

The growing disadvantage in the educational attainment of Mexican immigrants clearly implies a growing disadvantage in relative wages. Beginning in 1940, the IPUMS reports the worker's annual earned income in the year prior to the Census. We divided the reported annual earned income by the reported number of weeks worked (in the subsample of workers who reported a positive number of weeks worked) to calculate the weekly wage for each worker. ${ }^{10}$

Table 4 documents that the relative log weekly wage of both Mexican and non-Mexican immigrants fell steeply between 1940 and 2000. Panel A of the table reports the trend in the log weekly wage of male Mexican and non-Mexican immigrants relative to the log weekly wage of native-born working men. It is instructive to begin the discussion by observing the trend in the relative log weekly wage of non-Mexican immigrants. Table 4 shows that there was a sizable and steady decline in the relative wage of non-Mexican immigrants between 1940 and 2000. In

immigrant working men.

10 The sample includes self-employed workers. The worker's annual earned income is then defined as the sum of wage and salary income and self-employment income, except in 1940 when the Census does not report detailed information on self-employment income. Similar trends are revealed when the analysis is restricted only to salaried workers. 
1940, the typical non-Mexican immigrant man earned about .18 log points more than the typical native worker. By 2000, the typical non-Mexican immigrant man earned about .03 log points less than the typical native-born worker. This decline in the relative immigrant economic performance of immigrants has been a subject of intensive (and contentious) debate in recent years (Borjas 1985, 1995; Chiswick 1986; LaLonde and Topel 1992; Yuengert, 1994).

The table also shows that, although the magnitude of the wage disadvantage of Mexican immigrant men is much larger than that of their non-Mexican counterparts, there has not been a steady downward trend in relative economic performance among Mexican immigrants. For example, the log weekly wage of Mexican immigrants was -.48 log points lower than that of native-born workers in 1940. This wage disadvantage, in fact, narrowed to around -.39 log points by 1970 , before growing again to $-.53 \log$ points in 2000 . It is worth stressing that although the relative economic performance of Mexican immigrants does not seem to have worsened substantially over the past few decades, Mexican immigrants have always suffered a substantial handicap in the labor market. A log point difference of -.53 implies an approximate 41 percent wage gap relative to natives for Mexican immigrants, as compared to only a 3 percent wage gap for the non-Mexican immigrant population in 2000.

As we showed earlier, there has been an increasing gap in educational attainment between Mexican immigrants and native-born workers. It is of interest to determine, therefore, whether differences in educational attainment and other observed measures of human capital explain the sizable wage gap between Mexican immigrants and native men. To illustrate the key importance of observable socioeconomic characteristics in determining the relatively low wage of Mexican immigrants we estimated the following generic regression model separately in each Census: 


$$
\log w_{j t}=X_{j t} \beta_{t}+\delta_{t} I_{j t}+\varepsilon_{j t}
$$

where $w_{j t}$ gives the $\log$ weekly wage of worker $j$ in year $t ; X$ is a vector of socioeconomic characteristics (defined below); and $I_{j t}$ is a vector of two variables indicating if worker $j$ is a Mexican immigrant or a non-Mexican immigrant. Depending on the specification of the regression model, the vector $X$ can contain vector of dummy variables indicating the worker's education (less than high school, high school graduate, some college, or college graduate), a third-order polynomial in the worker's age, and a vector of fixed effects indicating the state of residence. ${ }^{11}$

Panel B of Table 4 reports the estimated coefficients of the parameter vector $\delta$ when the vector of standardizing variables includes only the worker's education and age. The results are striking. In 1940, the observed difference in socioeconomic characteristics, and particularly educational attainment, explain almost nothing of the sizable wage gap between Mexican immigrants and native-born men. The observed wage gap was -.475 log points and the adjusted wage gap was -.453 . By 1970, the minimal set of variables included in the vector $X$ is an important determinant of the wage gap. In 1970, the observed wage gap stood at -.390 log points and the adjusted wage gap was -.205 , so that the observed human capital variables explained roughly half of the observed wage gap. Beginning in 1980, the adjusted wage gap has remained stable at around -.15 log points, so that a very large fraction of the observed wage gap (over 70

11 This regression model can be easily expanded to allow for different vectors of coefficients for the various groups. This more general specification leads to results that are similar to those reported in the paper. For simplicity, we choose to report the findings from the most basic regression specification. 
percent of the -.53 wage gap in 2000) can be attributed to differences in socioeconomic characteristics, and particularly the very large difference in educational attainment. ${ }^{12}$

It also turns out that by 2000 the observed differences in human capital—and again most particularly the observed difference in educational attainment - explains practically all of the wage gap between non-Mexican immigrants and Mexican immigrants. In 2000, for example, the adjusted relative wage of non-Mexican immigrants is $-.07 \log$ points, in contrast to a $-.14 \log$ point difference for Mexican immigrants. The .07 log point difference in adjusted relative wages between the two groups of immigrant workers stands in sharp contrast to the $.50 \log$ point difference in observed wages. Put differently, practically the entire wage gap between the two groups of immigrants can be explained through the fact that they differ in their levels of observed human capital—particularly educational attainment.

Panel $\mathrm{C}$ of Table 4 replicates the regression analysis after adding in a vector of fixed effects indicating the worker's state of residence. These fixed effects could conceivably be very important since there is a great deal of geographic clustering among immigrants, and the states where immigrants tend to cluster may be high-wage states. The regression coefficients reported in the table, however, indicate that the quantitative changes in the size of the adjusted wage gaps are relatively small so that none of the key findings reported above are affected by the inclusion of the state fixed effects.

Finally, the bottom panels of Table 4 replicate the analysis using the sample of female workers. As noted earlier, the trends tend to be quite similar to those found among working men.

\footnotetext{
12 The fact that age and educational attainment explain a large part of the wage gap in recent decades but almost none of the gap in 1940 and 1950 is explained by the fact that, although there was a large gap in educational attainment in the earlier years, Mexican immigrants were substantially older than native workers in 1940 and 1950 and roughly the same age as natives after 1970. For example, the mean age of Mexican immigrants in 1940 was
} 
In 2000, the relative wage of female Mexican immigrants stood at -.40 log points, as compared to an advantage of $+.04 \log$ points for female non-Mexican immigrants. Much of the wage disadvantage experienced by Mexican immigrant women, however, disappears once the regression model controls for differences in educational attainment among the groups. In particular, the $-.40 \log$ point wage gap falls to a -.07 wage gap when the regression model controls for educational attainment and age. In other words, a minimal set of skill characteristics, explains about 80 percent of the wage gap between Mexican and native women.

\section{Cohort Effects}

The literature that documents the trends in immigrant skills stresses the importance of cohort and assimilation effects in generating the secular trends in the wage gap between immigrants and natives reported in Table 4. After all, the wage of Mexican (or non-Mexican) immigrants may be changing over time either because newer waves of immigrants have inherently different skills than earlier waves, or because earlier waves are acquiring valuable skills as they adapt to the U.S. labor market. It is of great interest to investigate the relative importance of both of these factors to examine the wage evolution experienced by the Mexicanborn workforce in the United States.

Instead of developing a parametric model to summarize the various trends, we use a simple framework that attempts to characterize the underlying trends without imposing any structure on the data. Consider, in particular, the trend in the relative wage of immigrants who, as

45.9 years, as compared to 36.4 years for natives. In 2000, the mean age of the two groups is 40.7 and 40.5 years, respectively. 
of the time of the Census, have been in the United States fewer than 5 years. ${ }^{13}$ The trend in the relative wage of these immigrants would identify the cohort effect that characterizes the most recent wave observed in each of the Censuses. ${ }^{14}$ Panel A of Table 5 reports the relative wage of these newly arrived Mexican and non-Mexican immigrants in each of the Censuses where the data are available.

The data clearly suggest a steady decline in the relative wage of successive waves of newly arrived Mexican immigrants from 1940 through 1990. The most recently arrived Mexican immigrant wave enumerated in the 1940 Census (i.e., the 1945-1949 arrivals) earned -.34 log points less than natives in 1940. By 1990, the latest wave of Mexican immigrants enumerated in that Census earned $.81 \log$ points less than natives. This decline was reversed slightly in the 1990s. In 2000, the latest wave of Mexican immigrants earned .76 log points less than native workers. To provide some perspective, note that a -.76 log wage gap implies a 53 percent wage differential between Mexican immigrants and natives at the time of arrival.

A similar decline in the relative wage of successive immigrant cohorts - although the magnitude of the relative wage disadvantage is not as large - is clear in the sample of nonMexican immigrants. In 1940, the most recently arrived non-Mexican immigrants earned .10 more log points than native workers; by 1970, the relative wage of the most recent cohort stood at -.16; by 1990 it stood at -29 . This long-term decline in the relative wage of newly arrived immigrants was reversed in the 1990s. In 2000, the newly arrived non-Mexican immigrants earned $.20 \log$ points less than native workers.

\footnotetext{
13 The 1950 Census does not provide this information so that the relative wage of the most recently arrived 5-year cohort cannot be measured.

14 This assertion, of course, assumes that the period effect is neutral between the immigrant population and the baseline reference group.
} 
The relative wage trends of successive immigrant cohorts of both Mexican and nonMexican immigrants, therefore, imply a very similar trend in cohort effects in the period between 1940 and 1990 - a decline in the relative earnings of newly arrived immigrants from 1940 through 1990, and then a reversal in the 1990s. This reversal was relatively modest for Mexican immigrants and quite sharp for non-Mexican immigrants.

Two points are worth emphasizing about these trends. First, although the U-shaped trends in cohort effects are very similar between the two groups of immigrants, the magnitude of the relative wage disadvantage at the time of entry is far greater for the Mexican population. In 2000, the typical newly arrived Mexican immigrant earned 53.4 percent less than the typical native worker, as compared to an 18.4 percent wage disadvantage for non-Mexican immigrants.

Secondly, a recent study by Borjas and Friedberg (2004) documents that the "uptick" in the cohort effect for (all) immigrants who arrived in the late 1990s can be explained in terms of a simple story that has significant policy relevance. In particular, the uptick documented in the entire sample of immigrants disappears when the relatively small number of immigrants who are employed as computer scientists and engineers is excluded from the analysis. ${ }^{15}$ In both 1980 and 1990, fewer than 5 percent of the newly arrived immigrants worked in these high-tech occupations. By 2000, however, 11.1 percent of the newly-arrived immigrants worked in these occupations.

Although the Census data does not provide information on the type of visa immigrants used to enter the country, it is probably not a coincidence that this increase in the relative number of high-tech immigrants occurred at the same time that the size of the H-1B visa

\footnotetext{
15 The occupation codes used to define the sample of computer scientists and engineers in each Census are: 80-93 in 1960; 3, 4, 6-23, in 1970; 44-59, 64, 229 in 1970 and 1980; 100-111, 132-153 in 2000.
} 
program grew substantially. This program allows employers to sponsor the entry of temporary workers in "specialty occupations." In fact, 70 percent of the workers entering the country with an H-1B visa in 2000 are employed either in computer-related occupations or in engineering (U.S. Immigration and Naturalization Service, 2002). Between 1990 and 1994, about 100,000 H1B visas were granted each year. In 1996 , this number increased to 144,548 ; to 240,947 in 1998 ; and to 302, 326 in 1999 (U.S. Immigration and Naturalization Service, various issues). It seems, therefore, that the "in-sourcing" of high-tech workers through the H-1B program reversed the long-standing trend of declining relative skills in successive cohorts of new immigrants.

It is extremely unlikely, however, that the H-1B program can explain the modest uptick observed in the cohort effects for Mexican immigrants during the late 1990s. After all, the number of Mexican-born workers in the newly arrived sample in the 2000 Census who are employed as computer scientists or engineers is miniscule ( 0.6 percent for Mexican immigrants as compared to 9.5 percent for non-Mexican immigrants). It seems, therefore, that the improvement in the relative economic status of newly arrived Mexican immigrants in the late 1990s may reflect either an increase in the overall skills of the sample or a period effect that is not yet fully understood (although it is well known that wages for low-skill workers increased markedly during this period as shown, for example, in Autor, Katz, and Kearney 2004).

Panel B of Table 5 continues the analysis of the cohort effects by reporting the adjusted wage differential between the sample of newly arrived immigrants and native-born workers when the regression model includes the age and education variables, and Panel $\mathrm{C}$ adds the state of residence fixed effects. The adjusted log wage differentials reported in the table are obtained by estimating a regression model similar to that presented in equation (1), but including only the samples of native workers and the most recently arrived immigrants in each Census. The 
comparison of the adjusted (from panel B) and unadjusted log wage gaps reveal a number of interesting findings. First, a minimal vector of skill characteristics explains a great deal of the wage gap between newly arrived Mexican immigrants and native workers, but explains only a relatively small part of the wage gap between non-Mexican immigrants and natives. For example, in 2000 there was a -.76 unadjusted log wage gap between recent Mexican immigrants and natives. Adjusting for differences in education and age reduces the wage gap to -.16 log points, so that the observed skill characteristics explain about 80 percent of the observed wage gap. In contrast, the observed wage gap for recent non-Mexican immigrants is $-.20 \log$ points and the adjusted wage gap is -.16 log points, so that differences in education and age explain only about a fifth of the observed wage gap in this population.

A second important insight provided by Table 5 is that the very large wage gap between non-Mexican and Mexican newly-arrived immigrants is almost entirely due to differences in educational attainment and age, particularly in recent years. In 2000, for example, the regression coefficients imply that there was an unadjusted wage gap of -.56 log points between Mexican and non-Mexican immigrants, but that adjusting for education and age reduced this wage gap to only about $-.015 \log$ points. In short, the regressions yield the important conclusion that the reason that recent Mexican immigrants earn far less than their non-Mexican counterparts has appears to have little to do with the fact that they are Mexican, but has almost everything to do with the fact that they are far less educated than their counterparts.

It is worth noting that the trend in relative wages between immigrants and native workers may also be reflecting differential period effects on the wages of the various groups, particularly towards the latter part of the period under study. After all, there were historic changes in the U.S. wage structure during the 1980s and 1990s, and these changes did not affect all skill groups 
equally (Katz and Murphy, 1992; Murphy and Welch, 1992). There was, for instance, a sizable increase in the wage gap between highly educated and less educated workers. Because Mexican immigrants are relatively unskilled, the changes in the wage structure imply that the relative wage of Mexican immigrants would have fallen between 1980 and 2000 even if the relative skills of Mexican immigrants had remained constant.

We use a simple approach to show that the wage trends documented in Tables 4 and 5 are not greatly affected by the changes in the wage structure. In particular, we calculated the median wage of Mexican or non-Mexican immigrants in each of the Census years starting in 1960, and computed the fraction of native workers whose wage lies below the immigrant median. This approach, of course, results in a statistic that marks the placement of the median Mexican or nonMexican immigrant in the native wage distribution. As shown in Table 6, the results of this analysis strongly resemble those provided by the trends in the mean log wage gap between immigrant and native workers. Among male workers, for example, the trend in the log wage gap between newly arrived Mexican immigrants and native workers suggested a general decline in the relative skills of the successive immigrant cohorts between 1960 and 2000. Similarly, the percentile analysis reported in Table 6 shows that the median newly-arrived Mexican immigrant in 1960 placed at the $17^{\text {th }}$ percentile of the native wage distribution, while the median newlyarrived Mexican immigrant in 2000 placed at the $12^{\text {th }}$ percentile.

Table 6 also reports the percentile placement of the immigrant workers after adjusting the data for differences in educational attainment, age, and state of residence between immigrants and natives. These adjusted placements are calculated by obtaining the residuals from a log weekly wage regression estimated separately by Census year and gender. The adjusted placement reported in the table gives the fraction of native workers who have a residual from this 
regression below that of the median residual in the samples of Mexican or non-Mexican workers.

As with the trends in the adjusted mean wage gap, the trend in the adjusted percentile placement suggest a decline in the relative skills of newly arrived non-Mexican immigrants from 1960 through 1990, and an increase in the relative skills of newly-arrived Mexican immigrants throughout the entire 1960-2000 period.

\section{Economic Assimilation}

The 1960-2000 Census data can also be used to measure the extent of "economic assimilation," the improvement in the relative wage of a specific immigrant cohort over time. ${ }^{16}$ We define an immigrant cohort in terms of calendar year of arrival and age at arrival. One can then use the decennial Censuses to calculate the wage differential between newly arrived immigrants and similarly aged natives as of 1970; to recalculate the wage gap between these same two groups ten years later in the 1980 Census when the workers are 10 years older; and to recalculate it again later in the 1990 and 2000 Censuses when the groups are 20 and 30 years older, respectively.

Consider initially the economic assimilation experienced by non-Mexican immigrants. Table 7 reports the economic assimilation trends for various cohorts of this group of immigrants. Figure 3 summarizes the results by illustrating the assimilation trends for workers who arrived in

16 It is believed that as many as one-third of the immigrants in the United States eventually return to their origin countries. Suppose that the return migrants are disproportionately composed of workers with lower than average wages. The intercensal tracking of a particular immigrant cohort would then indicate an improvement in relative wages even if no wage convergence is taking place. Alternatively, if the return migrants are the "successes" the rate of wage convergence would be underestimated. Because of data limitations, the selection mechanism generating the return migration flow is not well understood. An important exception is the work of Ramos (1992), who analyzes the return migration decisions of Puerto Ricans living in the United States. 
the United States when they were 25 to 34 years old. To simplify the presentation, much of our discussion will focus directly on the groups illustrated in Figure 3.

Consider the group of non-Mexican immigrants who arrived in the late 1960s at a relatively young age, when they were 25 to 34 years old. Figure 3 shows that these immigrants earned .11 log points less than comparably aged native workers at the time of entry. Let's now move forward in time ten years to 1980 , when both the immigrants and the natives are thirty-five to forty-four years old. The wage disadvantage experienced by these immigrants has now been reversed and the non-Mexican immigrant relative wage is $.01 \mathrm{log}$ points greater than that of comparably aged native workers. The economic assimilation of this group continues during the 1980s, so that the 1990 Census shows that the wage of this group of non-Mexican immigrants is about $.10 \log$ points greater than that of comparably aged natives. Finally, the data reveal relatively little additional wage growth during the 1990s as both native and immigrant workers near retirement. In sum, the process of economic assimilation exhibited by this cohort reduced the initial wage disadvantage of these immigrants by just over 20 log points over a thirty-year period - with most of the wage growth occurring in the first 20 years after immigration. Because this immigrant cohort had a relatively wage at the time of entry, the process of economic assimilation allowed the immigrants to narrow the wage disadvantage by "catching up" and overtaking comparable native workers.

The experience of other groups of non-Mexican immigrants who arrived at a relatively young age (between 25 and 34) yields roughly the same type of wage convergence regardless of the calendar year when they arrived in the United States. Consider, for instance, the nonMexican workers who arrived in the United States in the late 1970s. They started out with a wage disadvantage of $.18 \log$ points, and this disadvantage had disappeared within a decade. In 
short, the evidence suggests that non-Mexican immigrants experience reasonably rapid wage convergence, with the process of economic assimilation increasing the relative wage of the nonMexican immigrants who arrived at around age 30 by $20 \log$ points over the first two decades.

Contrast now these assimilation rates with those found in the population of similarly aged (i.e., 25-34 at the time of arrival) Mexican immigrants, as reported in Table 8 and illustrated in Figure 4. The figure reveals far less evidence of a consistent pattern of economic improvement for a particular cohort of immigrants over time. Although there is a great deal of variability in the data, the age-earnings profiles for the various cohorts of Mexican immigrants represented in the figure provide little evidence that these immigrants experience systematic and persistent wage growth as they accumulate experience in the U.S. labor market. To be specific, consider the evolution of relative wages for the Mexican immigrants who arrived in the late 1960s. They experienced a $-.59 \log$ point wage disadvantage at the time of entry; this disadvantage was narrowed substantially to $-.45 \log$ points by 1980 , but then it began to grow again, to $-.54 \log$ points in 1990 and $-.52 \log$ points in 2000 as the group of older workers now approached retirement age. Similarly, the sample of Mexican immigrants who arrived in the late 1970s, for example, experienced a flat assimilation path over their observable life cycle. In short, the evidence clearly indicates that the path of economic assimilation experienced by Mexican immigrants differs strikingly from that experienced by non-Mexican immigrants.

Tables 7 and 8 report more detailed evidence on the rate of economic assimilation for other cohorts of non-Mexican and Mexican immigrants who arrived at different ages. The evidence clearly suggests that immigrants (regardless of whether they are Mexican or not) who enter the United States at older ages enter with a greater disadvantage and experience less economic assimilation. For example, the relative wage of Mexican immigrants who arrived in 
the United States in the late 1970 s when they were 45 to 54 years old was -.82 log points at the time of entry. This group's relative wage had improved slightly to -.75 log points by 1990 . Similarly, the relative wage of comparably aged non-Mexican immigrants who entered the country in the late 1970 s was -.29 at the time of entry and had improved modestly to $-.18 \log$ points by 1990 .

In contrast, the data indicate that immigrants who enter the United States as children have a much smaller wage disadvantage when they first enter the labor market. Consider, for instance, the wage experience of non-Mexican immigrants who entered the United States in the late 1960s when they were 5 to 14 years old. These persons are first observed in the labor market in 1990 when they are 25 to 34 years old. Their entry wage stands at $+.09 \log$ points. Similarly, the wage of the respective cohort of Mexican immigrants is -.17 log points in 1990. Although Mexican immigrants still suffer a disadvantage, the size of the disadvantage is far smaller than that experienced by groups of Mexican immigrants who entered the United States at older ages (and, as we shall see momentarily, is roughly similar to the wage disadvantage experienced by U.S. born workers of Mexican ancestry).

A number of data and conceptual problems suggest that we should interpret the evolution of relative wages for specific cohorts of Mexican immigrants with some caution. For instance, it could be argued that the rates of economic assimilation convergence reported in Table 8 are misleading because they compare the wage growth experienced by the typical Mexican immigrant with the wage growth experienced by the typical U.S.-born worker. As we have seen, however, the educational attainment of the typical Mexican immigrant is much lower than the educational attainment of the typical native worker. In 1990, for example, only 4 percent of 
male native workers had 8 or fewer years of schooling, as compared to 57 percent of male Mexican immigrants.

This huge difference in the human capital of the two groups suggests that it may be of interest to compare the wage growth experienced by Mexican immigrants with the wage growth experienced by natives who face somewhat similar economic opportunities. Figure 5 replicates the economic assimilation analysis by using a different native group as the reference groupnamely the sample of native-born workers who report they have Mexican ancestry. ${ }^{17}$ The information on Mexican ancestry is available on a consistent basis only beginning with the 1980 Census so that this phase of the research focuses on the 1980-2000 period

It is of interest to contrast the age-earnings profiles illustrated in Figures 4 and 5. This contrast reveals two important findings. First, there is a much smaller wage gap between Mexican immigrants and Mexican "natives" than between Mexican immigrants and the typical native-born worker. For example, recently arrived Mexican immigrants aged 25-34 in 1980 earned $.50 \log$ points less than the typical young native worker at the time, but earned only -.04 $\log$ points less than the typical U.S.-born worker of Mexican ancestry. Second, although there is a great deal of variability in the age-earnings profiles, there is somewhat more evidence of a “catching up" effect for Mexican immigrants relative to U.S. natives of Mexican ancestry. Figure 5, in fact, suggests that Mexican immigrants (at least starting with those arriving in the 1970s) experience roughly a $.10 \log$ point catching up effect during their first decade in the United States.

\footnotetext{
17 The next section discusses the construction of the sample of Mexican-born workers in the post-1980 Censuses in detail.
} 
There is even stronger evidence of wage convergence when the Mexican immigrants are compared to native workers who have the same educational attainment. As shown above, the fraction of Mexican men who are high school dropouts hovered around 90 percent prior to 1960 and was still around 63 percent even by 2000 . It is of interest, therefore, to contrast how the bulk of the Mexican immigrant workforce fares relative to the (shrinking) sample of native high school dropouts. Figure 6 shows that the wage of Mexican immigrant high school dropouts increases significantly during their first decade in the United States relative to that of native high school dropouts. For example, the newly arrived immigrants aged 25-34 in 1970 earned -.46 log points less than native high school dropouts, but this wage gap had narrowed to -.17 log points by 1980 . Note, however, that this wage convergence slows down considerably (if not stop altogether) after 10 years in the United States, so that Mexican immigrants earn substantially less than comparably aged native high school dropouts even after 20 years in the country.

In addition to the problems introduced by the choice of a baseline group, it is worth stressing that the interpretation of the wage evolution experienced by a particular Mexican immigrant cohort as a measure of economic assimilation ignores the fact that the sample composition of the Mexican immigrant sample is likely changing over time because of return migration. The proximity of Mexico to the United States, and the presumed large back-and-forth migration flows between the two countries, suggests that Mexican immigrants may have relatively large out-migration rates. ${ }^{18}$ It is evident that the use of synthetic cohorts created by

\footnotetext{
18 Borjas and Bratsberg (1996), for example, estimate that about 25.9 percent of the legal Mexican immigrants who arrived between 1970 and 1974 had left the United States by 1980. This outmigration rate compares to a rate of 21.5 percent for all legal immigrants who arrived between 1970 and 1974 .
} 
matching particular groups of workers across Census surveys may not lead to an accurate assessment of economic assimilation for a population that has a large transient component. ${ }^{19}$

Suppose, for instance, that the return migrants are disproportionately composed of workers who have lower than average wages. The intercensal tracking of a particular immigrant cohort (defined in terms of calendar year of entry and age at migration) would then indicate an improvement in relative wages even if no wage convergence is taking place. Alternatively, the rate of wage convergence would be underestimated if the return migrants are the "successes."

The United States does not collect any information on either the size or the skill composition of the out-migrant flow. As a result, the available Census data cannot conclusively determine the biases introduced by selective return migration on the observed rate of economic assimilation. Nevertheless, there are relatively simple ways of ascertaining the potential importance of this bias. For example, let $\bar{w}_{0}$ be the relative log weekly wage of a cohort of Mexican immigrants at the time of entry $(t=0)$, and let $w_{1}^{S}$ be the relative log weekly wage of the sample of survivors in the following period (that is, the relative wage of those immigrants who chose to remain in the United States). Assume that there is no sample attrition in the nativeborn population and that a fraction $r$ of the immigrants will return to Mexico between $t=0$ and $t$ $=1$. We can then write the observed rate of wage convergence for this particular cohort of immigrants as:

$$
w_{1}^{S}-\bar{w}_{0}=w_{1}^{S}-\left[(1-r) w_{0}^{S}+r w_{0}^{R}\right]
$$

\footnotetext{
19 The multiple trips across the border made by many Mexican immigrants also raises issues concerning the accuracy and interpretation of the responses by this group to the U.S. Census question on year of arrival in the
} 
where $w_{0}^{S}$ is the average relative entry wage of immigrants who remained in the United States; and $w_{0}^{R}$ is the average relative entry wage of the immigrants who returned to Mexico. It is instructive to rewrite equation (3) as:

$$
w_{1}^{S}-\bar{w}_{0}=\left(w_{1}^{S}-w_{0}^{S}\right)+r\left(w_{0}^{S}-w_{0}^{R}\right),
$$

which shows the relation between the observed rate of wage growth and the true rate of wage growth $\left(w_{1}^{S}-w_{0}^{S}\right)$ actually experienced by the sample of survivors. The observed rate of wage growth is a biased measure of the true rate of wage convergence as long as the skill composition of the sample of survivors differs from that of the sample of return migrants (that is, as long as $\left.w_{0}^{S} \neq w_{0}^{R}\right)$.

We do not have any direct empirical evidence indicating the extent to which the entry wage of Mexican immigrants who remain in the United States differs from the entry wage of Mexican immigrants who return to Mexico. Equation (4), however, suggests that the numerical importance of the bias introduced by nonrandom return migration will not be very "large" for reasonable parameter values. Suppose, for instance, that the rate of return migration among Mexican immigrants who were enumerated by the U.S. Census at some point of their U.S. sojourn is as high as 30 percent. If the wage differential between the Mexicans who remain in the United States and those who leave is on the order of .2 log points (favoring the immigrants who return to Mexico), equation (4) then indicates that the true rate of wage convergence is about $6 \log$ points higher than the observed rate of wage convergence. The data in Table 8 , 
however, suggest that there would still be relatively little evidence of substantial wage convergence even if we add $6 \log$ points to the wage growth experienced by the surviving Mexican immigrants. In short, it is very unlikely that the bulk of the Mexican immigrant influx will ever reach wage parity with the native-born workforce.

\section{Native-Born Workers of Mexican Ancestry}

As noted earlier, beginning with the 1980 Census, we can observe the socioeconomic characteristics of native-born persons who are of Hispanic origin and who in addition claim that their Hispanic ancestry is of Mexican origin. The number of native-born workers of Mexican ancestry in the U.S. workforce has grown rapidly in the past 20 years and is inevitably going to grow even faster in the future. As a result, it is of great interest to determine the skills and characteristics of these workers in the labor market. Note that this population does not necessarily consist of only second-generation workers, as many workers of higher-order generations may claim Mexican ancestry. Nevertheless, the entry of many second-generation workers of Mexican ancestry in the near future is bound to lead to a substantial increase in the demographic and economic importance of this population in the U.S. labor market.

There has been a rapid growth in the size of the population of native-born workers who are of Mexican ancestry in the past two decades. In 1980, 2.3 percent of the native-born male workforce and 2.3 percent of the native-born female workforce was of Mexican ancestry. By 2000, these statistics had increased to 3.1 and 3.0 percent. It is of interest to note that if one combines the population of Mexican-born workers with that of U.S.-born workers of Mexican ancestry, the 2000 Census indicates that these two groups combined make up 7.7 percent of the male workforce in the United States and 5.4 percent of the female workforce. These statistics 
stand in sharp contrast to the data in 1980, where only 3.5 percent of the male workforce and 2.9 percent of the female workforce could be classified as of Mexican origin.

Table 9 documents the sizable difference in the distributions of educational attainment between native-born Mexicans and other native-born workers. Like their immigrant counterparts, native-born Mexicans have disproportionately large high school dropout rates and disproportionately low rates of college graduation. In 2000, for example, 21.0 percent of nativeborn Mexicans were high school dropouts and only 11.3 percent were college graduates. This contrasts strikingly with the 8.3 percent of native-born non-Mexicans who were high school dropouts and 27.9 percent who were college graduates. It is worth stressing that although nativeborn Mexicans have relatively low educational attainment (relative to other native-born workers), they are far more educated than the Mexican immigrant workforce, where dropout rates are around 63 percent in 2000.

The sizable differences in the educational attainment (as well as in the occupations) of Mexican native workers and other natives inevitably lead to equally sizable differences in log weekly wages between the two groups. We use the generic regression framework given by equation (1) to estimate the adjusted wage differentials separately in each of the Censuses since 1980. We expand the immigration status variable to include dummy variables indicating if the worker is native-born of Mexican ancestry, an immigrant of Mexican origin, a non-Mexican immigrant, and a native-born worker of non-Mexican ancestry (the omitted group).

Panel A of Table 10 reports the trend in the unadjusted relative log weekly wage between the various groups and the baseline group of non-Mexican native born workers. In 1980, the unadjusted log weekly wage of Mexican immigrants was .41 log points below that of nonMexican natives. By 2000, this gap had grown to $-.54 \log$ points. It turns out that the economic 
status of native-born workers of Mexican ancestry also deteriorated significantly over this period, from -.24 log points in 1980 to $-.31 \log$ points in 2000 .

The table also shows, however, that as with the Mexican immigrant sample, observable variables, and particularly educational attainment, tends to explain much of the gap between native-born Mexicans and the baseline group. By adjusting simply for differences in educational attainment and age, the observed log wage gap of $-.31 \log$ points for Mexican natives falls to -.08 $\log$ points. In other words, nearly three-quarters of the wage differential between native-born workers of Mexican ancestry and other native-born workers is due to differences in a minimal set of observable measures of educational attainment and age. ${ }^{20}$

The empirical analysis in the previous section was unable to document that Mexican immigrants experience substantial rates of economic assimilation during the immigrants' work life. The empirical analysis summarized in Table 10 shows that a large part of the wage disadvantage of Mexican immigrants is likely to persist into the next generation. It seems, therefore, that the very large Mexican immigrant influx that entered the United States in recent decades has experienced and will likely continue to experience a very different path of economic adaptation than other immigrant waves. The reasons for the lagging economic performance of this large and fast-growing population will likely be a central concern of social science research for decades to come.

\section{Labor Market Impact and Economic Benefits}

Economic theory implies that immigration should lower the wage of competing workers and increase the wage of complementary workers. For example, an influx of foreign-born 
laborers reduces the economic opportunities for laborers-all laborers now face stiffer competition in the labor market. At the same time, high-skill natives may gain substantially. They pay less for the services that laborers provide, such as painting the house and mowing the lawn, and natives who hire these laborers can now specialize in producing the goods and services that better suit their skills.

Because of the policy significance associated with determining the impact of immigration on the employment opportunities of native workers, a large literature developed in the past two decades attempting to measure this impact. The starting point for much of this literature is the fact that immigrants in the United States cluster in a small number of geographic areas. Practically all empirical studies in the academic literature exploit this geographic clustering to define the empirical exercise that purports to measure the labor market impact of immigration. ${ }^{21}$ The typical study defines a metropolitan area (or state) as the labor market that is penetrated by immigrants. The study then goes on to calculate a cross-city correlation measuring the relation between the native wage in a locality and the relative number of immigrants in that locality. A negative correlation, indicating that native wages are lower in markets with many immigrants, would suggest that immigrants worsen the employment opportunities of competing native workers.

There is a great deal of dispersion in the findings reported by the various studies in this empirical literature. Nevertheless, there is a tendency for the estimated cross-city correlations to cluster around zero, helping to create the conventional wisdom that immigrants have little impact on the labor market opportunities of native workers, perhaps because "immigrants do jobs that

\footnotetext{
${ }^{20}$ See also Trejo (1997).

${ }^{21}$ Representative studies include Altonji and Card (1991), Card (1990, 2001), and Grossman (1982).
} 
natives do not want to do." It would seem, therefore, that a fundamental implication of the standard textbook model of the labor market — that an increase in supply lowers wages — is soundly rejected by the data.

Recent research, however, raises two questions about the validity of interpreting nearzero cross-city correlations as evidence that immigration has no labor market impact. First, immigrants may not be randomly distributed across labor markets. If immigrants tend to cluster in cities with thriving economies (and high wages), there would be a built-in positive correlation between immigration and wages. This positive correlation would certainly attenuate, and perhaps even reverse, whatever negative impact immigration might have had on wages in local labor markets.

Second, natives may respond to the wage impact of immigration by moving their labor or capital to other cities. For example, native-owned firms see that cities in Southern California flooded by low-skill immigrants pay lower wages to laborers. Employers who hire laborers will want to relocate to those cities. The flow of jobs to the immigrant-hit areas cushions the adverse effect of immigration on the wage of competing workers in those localities. Similarly, laborers living in Michigan were perhaps thinking about moving to California before the immigrants entered that state. These laborers learn that immigration reduced their potential wages in California and may instead decide to remain where they are or move elsewhere. Moreover, some Californians might leave the state to search for better opportunities.

The flows of capital and labor tend to equalize economic conditions across cities. As a result, inter-city comparisons of native wage rates will not be very revealing: capital flows and native migration diffuse the impact of immigration across the national economy. In the end, all laborers, regardless of where they live, are worse off because there are now many more of them. 
Because local labor markets adjust to immigration, a number of recent studies have emphasized that the labor market impact of immigration may be measurable only at the national level. ${ }^{22}$ Borjas (2003) used this insight to examine the link between immigration and the evolution of wages for specific skill groups in the past few decades. His study indicates that by analyzing national trends in the labor market and by defining skill groups in terms of both educational attainment and work experience, one can make substantial progress in determining how immigration alters the employment and earnings opportunities of native workers.

The empirical analysis reported in this section estimates a labor demand model developed by Borjas (2003) to simulate the impact of the Mexican immigrant influx on the wages of competing workers. We restrict the simulation to male workers observed in the 1980 and 2000 Censuses. As in Borjas (2003), the men are classified into four distinct education groups: persons who are high school dropouts, high school graduates, persons who have some college, and college graduates. Work experience is defined as the number of years that have elapsed since the person completed school. ${ }^{23}$ The analysis is restricted to workers with 1 to 40 years of experience. Workers are then grouped into eight different experience groups, indicating if the worker has 1-5 years of experience, 6-10 years, 11-15 years, and so on. There are, therefore, a total of 32 skill groups in the labor market (four education and eight experience groups).

\footnotetext{
22 Borjas, Freeman, and Katz (1997) proposed the hypothesis that the labor market impact of immigration may only be measurable at the national level.

23 The analysis assumes that the age of entry into the labor market is 17 for the typical high school dropout, 19 for the typical high school graduate, 21 for the typical person with some college, and 23 for the typical college graduate. We restrict the analysis to persons who have between 1 and 40 years of experience. By restricting the sample to male workers, we are assuming a form of production separability between men and women in the production process. The inclusion of women in the analysis does not greatly affect the results, even though the allocation of women into the various labor market experience groups likely contains a great deal of measurement error.
} 
As in Borjas (2003), suppose the aggregate production function for the national economy at time $t$ is:

$$
Q_{t}=\left[\lambda_{K t} K_{t}^{v}+\lambda_{L t} L_{t}^{v}\right]^{1 / v}
$$

where $Q$ is output, $K$ is capital, $L$ denotes the aggregate labor input; and $v=1-1 / \sigma_{K L}$, with $\sigma_{K L}$ being the elasticity of substitution between capital and labor $(-\infty<v \leq 1)$. The vector $\lambda$ gives technology parameters that shift the production frontier, with $\lambda_{K t}+\lambda_{L t}=1$. The aggregate $L_{t}$ incorporates the contributions of workers who differ in both education and experience. Let:

$$
L_{t}=\left[\sum_{i} \theta_{i t} L_{i t}^{\rho}\right]^{1 / \rho},
$$

where $L_{i t}$ gives the number of workers with education $i$ at time $t$, and $\rho=1-1 / \sigma_{E}$, with $\sigma_{E}$ being the elasticity of substitution across these education aggregates $(-\infty<\rho \leq 1)$. The $\theta_{i t}$ give timevariant technology parameters that shift the relative productivity of education groups, with $\Sigma_{i} \theta_{i t}$ $=1$. Finally, the supply of workers in each education group is itself given by an aggregation of the contribution of similarly educated workers with different experience. In particular,

$$
L_{i t}=\left[\sum_{j} \alpha_{i j} L_{i j t}^{\eta}\right]^{1 / \eta},
$$


where $L_{i j t}$ gives the number of workers in education group $i$ and experience group $j$ at time $t$ (given by the sum of $N_{i j t}$ native and $M_{i j t}$ immigrant workers); and $\eta=1-1 / \sigma_{X}$, with $\sigma_{X}$ being the elasticity of substitution across experience classes within an education group $(-\infty<\eta \leq 1)$. Equation (7) assumes that the technology coefficients $\alpha_{i j}$ are constant over time, with $\Sigma_{j} \alpha_{i j}=1$. Borjas (2003) shows that the key parameters $\sigma_{X}$ and $\sigma_{\mathrm{E}}$ can be estimated by regressing the log wage of particular education-experience groups on the log of the size of the workforce in the various cells, and instrumenting the supply variable by the immigrant share in that skill cell. We re-estimated the econometric framework using data from the 1960-2000 IPUMS samples. ${ }^{24}$ Our elasticity estimates are $\sigma_{X}=2.9$ and $\sigma_{E}=2.3$. The empirical implementation of the threelevel CES technology described above does not use any data on the aggregate capital stock so that $\sigma_{K}$ cannot be directly estimated. Hamermesh (1993, p. 92) concludes that the aggregate U.S. economy can be reasonably described by a Cobb-Douglas production function, suggesting that $\sigma_{K L}$ equals one. We use this estimate in the simulation reported below.

The factor price elasticity giving the impact on the wage of factor $y$ of an increase in the supply of factor $z$ is defined by:

$$
\varepsilon_{y z}=\frac{d \log w_{y}}{d \log L_{z}}
$$

It is easy to show that the factor price elasticities depend on the income shares accruing to the various factors and on the three elasticities of substitution that lie at the core of the three-level

\footnotetext{
${ }^{24}$ Borjas (2003) estimated the model using data from the 1960-1990 Census and from the merged 19992001 Current Population Surveys. The elasticity estimates obtained using the 1960-2000 Census data differ slightly from those reported in the original paper.
} 
CES framework. ${ }^{25}$ The marginal productivity condition for the typical worker in education group $s$ and experience group $x$ can be written as $w_{s x}=D\left(K, L_{11}, \ldots, L_{18}, \ldots, L_{41}, \ldots, L_{48}\right)$. Assuming that the capital stock is constant, the net impact of immigration on the log wage of group $(s, x)$ is:

$$
\Delta \log w_{s x}=\varepsilon_{s x, s x} m_{s x}+\sum_{j \neq x} \varepsilon_{s x, s j} m_{s j}+\sum_{i \neq s} \sum_{j} \varepsilon_{s x, i j} m_{i j}
$$

where $m_{i j}$ gives the percentage change in labor supply due to immigration in cell $(i, j)$. Because the size of the native labor force in each skill group is shifting over time, Define $m_{i j}$ as:

$$
m_{i j}=\frac{M_{i j, 2000}-M_{i j, 1980}}{0.5\left(N_{i j, 1980}+N_{i j, 2000}\right)+M_{i j, 1980}},
$$

so that the baseline population used to calculate the percent increase in labor supply averages out the size of the native workforce in the skill cell and treats the pre-existing immigrant population as part of the "native" stock.

The top panel of Table 11 summarizes the results of the simulation. The immigrant influx of the 1980s and 1990s lowered the wage of most native workers, particularly of those workers at the bottom and top of the education distribution. The wage fell by 8.2 percent for high school dropouts and by 3.8 percent for college graduates. In contrast, the wage of high school graduates

\footnotetext{
25 We assume that the share of income accruing to all labor groups is 0.7 . We then used data from the 1990 Census to calculate the income share accruing to each of the various education-experience cells.
} 
and workers with some college fell by just over 2 percent. Overall, the immigrant influx from 1980 to 2000 is estimated to have reduced the wage of the typical native worker by 3.3 percent.

This framework provides a simple mechanism for establishing the labor market impact of Mexican immigration. In particular, we simulated the model to predict a new set of labor market impacts under the counterfactual assumption that there had been no Mexican immigration (either legal or illegal) between 1980 and 2000. This assumption redefines the labor supply shocks defined in equation (1). In particular, consider:

$$
m_{i j}^{*}=\frac{M_{i j, 2000}^{*}-M_{i j, 1980}}{0.5\left(N_{i j, 1980}+N_{i j, 2000}\right)+M_{i j, 1980}},
$$

where $M_{i j, 2000}^{*}$ gives the size of the immigrant workforce in skill group $(i, j)$ in 2000 under the assumption that no Mexican immigrants entered the United States between 1980 and 2000.

The second column of Table 11 shows the predicted labor market effects when the supply shocks are given by equation (1). Mexican immigration, which is predominantly low-skill, accounts for all of the adverse impact of immigration on low-skill native workers. It is also worth noting that the earnings of college graduates would have fallen by 3.9 percent if there had been no Mexican immigration, as compared to the 3.8 percent decline that occurred with the actual flow. In other words, the influx of low-skill Mexican immigrants barely improves the wage of high-skill workers.

As emphasized above, these simulations assume the capital stock is constant so that the results summarized in the top panel of Table 11 represent the short-run impact of immigration. An alternative simulation would measure the impacts under the assumption that the capital stock 
adjusts completely to the increased labor supply. In effect, this alternative simulation would assume that the rental price of capital (rather than the capital stock) is constant. In other words, the adjustment of the capital stock to immigration would reduce the rental rate of capital back to its pre-existing, equilibrium level.

The maintained assumption that $\sigma_{K L}$ equals one implies that the predicted long-run wage impact on the log wage of group $(s, x)$ is:

$$
\Delta \log w_{s x}=s_{K} \tilde{K}+\varepsilon_{s x, s x} m_{s x}+\sum_{j \neq x} \varepsilon_{s x, s j} m_{s j}+\sum_{i \neq s} \sum_{j} \varepsilon_{s x, i j} m_{i j}
$$

where $s_{K}$ is capital's share of income (assumed to be 0.3 ); and $\tilde{K}$ is the percent change in the capital stock induced by immigration. The assumption that $\sigma_{K L}$ is unity implies that the change in the capital stock is a weighted average of the immigrant supply shocks in the various educationexperience groups, where the weights are the shares of income accruing to the various groups. ${ }^{26}$

The bottom panel of Table 11 uses equation (12) to predict the long-run impact of the 1980-2000 immigrant influx. As expected, the labor market impact of immigration is muted in the long-run, as capital adjusts to the increased workforce. In fact, there's barely a change in the wage of the typical worker. The unbalanced nature of the immigrant supply shock in terms of the skill distribution, however, implies that there are distributional effects. The first column of the table reveals that high school dropouts still experience a sizable wage reduction, even in the long

26 To simplify notation, let $n$ be the subscript indicating the education-experience skill group $(n=1, \ldots, 32)$. The implied change in the capital stock $\tilde{K}=\sum_{n} s_{n} m_{n} / s_{L}$, where $s_{L}$ is labor's share of income. Note that equation (12) differs from equation (9) only by adding the constant $s_{k} \tilde{K}$ to each group. Put differently, full capital adjustment alters the absolute wage impact of immigration but leaves the relative wage effects unchanged. 
run, of about 4.8 percentage points. The increase in the capital stock, however, completely removes the wage loss suffered by college graduates.

The second column of the panel shows the predicted long-run impact under the counterfactual that no Mexicans migrated to the United States between 1980 and 2000. It is evident that in the absence of Mexican immigration, low-skill workers would have benefited (through a 2.7 percent wage increase) from the complementarities that arise when the immigrant influx is composed mainly of high-skill workers.

Immigration may also affect the economic welfare of natives through its impact on the relative prices of goods and services. ${ }^{27}$ The skill distribution of Mexican immigrants and their concentration in low-skill occupations suggest that Mexican immigration may serve to expand the supply and lower the U.S. prices of non-traded goods and services that are low-skill labor intensive. In fact, a much larger share of Mexican immigrants than of U.S. natives is employed in low-skill service jobs such as private household occupations, food preparation occupations, and gardening. In 2000, for example, 20.9 percent of Mexican immigrants and only 6.5 percent of native-born workers were employed in the subset of occupations classified as "food preparation and serving" or "buildings and grounds cleaning and maintenance." American consumers who spend more on low-skill intensive non-traded goods and services will tend to disproportionately benefit from the recent wave of Mexican immigration.

Some recent exploratory work has exploited cross-area variation in changes in low-skill immigrants as a share of the workforce to estimate the impacts of increased low-skill immigration on the supply and prices of low-skill intensive services. This approach will tend to

\footnotetext{
27 Rivera-Batiz (1983) provides a useful summary of the implications of alternative multi-sector trade models for the distributional impacts on rich countries of low-skill immigration from poor to rich countries.
} 
understate the price impacts on non-traded services intensively employing new low-skill immigrants to the extent the expansion in the overall national supply of less-educated workers also affects low-immigrant receiving areas by altering native labor and capital flows. Khananusapkul (2004) finds using U.S. Census data from 1970 to 2000 that a one percentage point increase in the share of low-skill female immigrants in a metropolitan area increases the proportion of private household workers by 6 percentage points and lowers the wages in the private household sector by 3 percent. This evidence indicates a direct supply expansion in the low-skill female intensive sector when more low-skill female immigrants are available in a labor market. Cortes (2004) examines the impacts on prices and consumer expenditures on some nontraded services of changes in the ratio of low-skill Mexican immigrants to native workers across U.S. metropolitan areas and states from 1980 to 2000. She presents suggestive (but quite imprecise) preliminary estimates indicating an increase in low-skill Mexican immigrants to an areas reduces the price of food away from home and increase the share of household reporting expenditures on housekeeping, gardening, and food away from home.

The large growth and predominantly low-skilled nature of Mexican immigration to the United States over the past two decades appears to have played a modest role in the widening of the U.S. wage structure by adversely affecting the earnings of less-educated native workers and improving the earnings of college graduates. U.S. natives (particularly high-skill natives) are likely to benefit from greater availability and reduced prices of non-traded goods and services that are intensive in low-skill labor.

\section{Summary}


This paper uses the IPUMS data from 1900 through 2000 to document the evolution of the Mexican-born workforce in the U.S. labor market. It is well known, of course, that there has been a rapid rise in Mexican immigration to the United States in recent years. Interestingly, the share of Mexican immigrants in the U.S. workforce declined steadily beginning in the 1920s before beginning to rise in the 1960s. It was not until 1980 that the relative number of Mexican immigrants in the U.S. workforce was at the 1920 level.

The analysis of the economic performance of these immigrants throughout the $20^{\text {th }}$ Century yields a number of interesting and potentially important findings:

1. Mexican immigrants have much less educational attainment than either native-born workers or non-Mexican immigrants. These differences in human capital account for nearly three-quarters of the very large wage disadvantage suffered by Mexican immigrants in recent decades.

2. Although the earnings of non-Mexican immigrants converge to those of their nativeborn counterparts as the immigrants accumulate work experience in the U.S. labor market, this type of wage convergence has been much weaker on average for Mexican immigrants than for other immigrant groups.

3. Although native-born workers of Mexican ancestry have levels of human capital and earnings that far exceed those of Mexican immigrants, the economic performance of these native-born workers lags behind that of native workers who are not of Mexican ancestry. Much of the wage gap between the two groups of native-born workers can be explained by the large difference in educational attainment between the two groups.

4. The large Mexican influx in recent decades widened the U.S. wage structure by adversely affecting the earnings of less-educated native workers and improving the earnings of 
college graduates. These wage effects have, in turn, lowered the prices of non-traded goods and services that are low-skill labor intensive.

There is little evidence that the influx of Mexican-born workers into the United States is slowing down as we enter a new century, and there is also little evidence that the skill composition of the Mexican influx is changing from what it has been in the past. The continued migration of Mexican workers into the United States, and the inevitable rapid growth of the group of native-born workers of Mexican ancestry, suggest that the economic consequences of this low-skill migration influx are only beginning to be felt. 


\section{REFERENCES}

Altonji, Joseph G. and Card, David. "The Effects of Immigration on the Labor Market Outcomes of Less-Skilled Natives," in J.M. Abowd and R.B. Freeman, eds., Immigration, Trade, and the Labor Market. Chicago: University of Chicago Press, 1991, 201-234.

Autor, David H., Lawrence F. Katz, and Melissa S. Kearney, “Trends in U.S. Wage Inequality: Re-Assessing the Revisionists," unpublished paper, Harvard University, August 2004.

Borjas, George J., "Assimilation, Changes in Cohort Quality, and the Earnings of Immigrants," Journal of Labor Economics 3 (1985), 463-489.

Borjas, George J., "Assimilation and Changes in Cohort Quality Revisited: What Happened to Immigrant Earnings in the 1980s?” Journal of Labor Economics 13 (1995), 201245.

Borjas, George J., "The Labor Demand Curve Is Downward Sloping: Reexamining the Impact of Immigration on the Labor Market," Quarterly Journal of Economics 118 (November 2003), 1335-74.

Borjas, George J. and Bernt Bratsberg, "Who Leaves? The Outmigration of the ForeignBorn," Review of Economics and Statistics 78 (February 1996), 165-176.

Borjas, George J. and Rachel Friedberg, "The Trend in Immigrant Earnings and Skills Over the 1990s," Working Paper, Harvard University, 2004.

Borjas George J., Richard B. Freeman, and Lawrence F. Katz, "How Much Do Immigration and Trade Affect Labor Market Outcomes?," Brookings Papers on Economic Activity 1997, no. 1, 1-67.

Camarota, Stephen A. Immigration from Mexico: Assessing the Impact on the United States. Washington, DC: Center for Immigration Studies, 2001.

Card, David, "The Impact of the Mariel Boatlift on the Miami Labor Market," Industrial and Labor Relations Review 43 (1990), 245-257.

Card, David, "Immigrant Inflows, Native Outflows, and the Local Labor Market Impacts of Higher Immigration,” Journal of Labor Economics 19 (January 2001), 22-64.

Card, David and Ethan Lewis, "The Diffusion of Mexican Immigrants During the 1990s: Explanations and Impacts,” Working Paper, UC Berkeley, 2005.

Chiswick, Barry R. "Is the New Immigration Less Skilled than the Old?" Journal of Labor Economics 4 (April 1986), 168-192. 
Cortes, Patricia, "How Much Does Low-Skilled Immigration Decrease Prices?," unpublished paper, MIT, November 2004.

Feliciano, Zadia, "The Skill and Economic Performance of Mexican Immigrants from 1910 to 1990," Explorations in Economic History 38 (2001), 386-409.

Funkhouser, Edward and Stephen J. Trejo, "The Labor Market Skills of Recent Male Immigrants: Evidence from the Current Population Surveys," Industrial and Labor Relations Review 48 (1995), 792-811.

Grossman, Jean Baldwin, "The Substitutability of Natives and Immigrants in Production," Review of Economics and Statistics 54 (November 1982), 596-603.

Hamermesh, Daniel S., Labor Demand. Princeton, N.J.: Princeton U. Press, 1993.

Katz, Lawrence F. and Kevin M. Murphy, "Changes in the Wage Structure, 1963-87: Supply and Demand Factors," Quarterly Journal of Economics 107 (February 1992), 35-78.

Khananusapkul, Phanwadee, "Do Low-Skilled Female Immigrants Increase the Labor Supply of Skilled Women?," unpublished paper, Harvard University, February 2004.

LaLonde, Robert J. and Robert H. Topel, "The Assimilation of Immigrants in the U.S. Labor Market," in G.J. Borjas and R.B. Freeman, eds., Immigration and the Work Force: Economic Consequences for the United States and Source Areas. Chicago: University of Chicago Press, 1992, 67-92.

Marcell, Ronald. O. "Bracero Program Hurt Domestic Farm Workers," Borderlands 12 (Spring 1994), 13-14.

Massey, Douglas S. and Z. Liang, "The Long-Term Consequences of a Temporary Worker Program: The U.S. Bracero Experience," Population Research and Policy Review, 1989.

Massey, Douglas S., Jorge Durand, and Nolan J. Malone, Beyond Smoke and Mirrors. New York: Russell Sage Foundation, 2002.

Murphy, Kevin M., and Finis Welch, “The Structure of Wages,” Quarterly Journal of Economics 107 (February 1992), 285-326.

Ramos, Fernando. "Out-Migration and Return Migration of Puerto Ricans," in G.J. Borjas and R.B. Freeman, eds., Immigration and the Work Force: Economic Consequences for the United States and Source Areas. Chicago: University of Chicago Press, 1992, 49-66.

Redstone, Ilana and Douglas S. Massey, "Coming to Stay: An Analysis of the U.S. Census Question on Immigrants' Year of Arrival,” Demography 41 (2004): 721-738. 
Rivera-Batiz, Francisco L. "Trade Theory, Distribution of Income, and Immigration," American Economic Review 73 (May 1983), 183-187.

Trejo, Stephen J., “Why Do Mexican-Americans Earn Low Wages?," Journal of Political Economy, 105 (1997), 1235-68.

Trejo, Stephen J., "Intergenerational Progress of Mexican-Origin Workers in the U.S. Labor Market," Journal of Human Resources 38 (2003), 467-89.

U.S. Bureau of the Census, Historical Statistics of the United States, Colonial Times to 1970, Bicentennial Edition, Part 1. Washington, D.C.: U.S. Government Printing Office, 1975.

U.S. Census Bureau, The Foreign Born Population: 2000, Census 2000 Brief, 2003, http://www.census.gov/prod/2003pubs/c2kbr-34.pdf

U.S. Department of Commerce, U.S. Census Bureau, Statistical Abstract of the United States: 2004-5. Washington, D.C.: U.S. Government Printing Office, 2004.

U.S. Immigration and Naturalization Service, Statistical Yearbook of the Immigration and Naturalization Service. Washington, D.C.: U.S. Government Printing Office, various issues.

Yuengert, Andrew. "Immigrant Earnings, Relative to What? The Importance of Earnings Function Specification and Comparison Points," Journal of Applied Econometrics 9 (JanuaryMarch 1994), 71-90. 
Figure 1. Growth of Mexican Immigrants in the U.S. workforce, 1900-2000

A. All workers

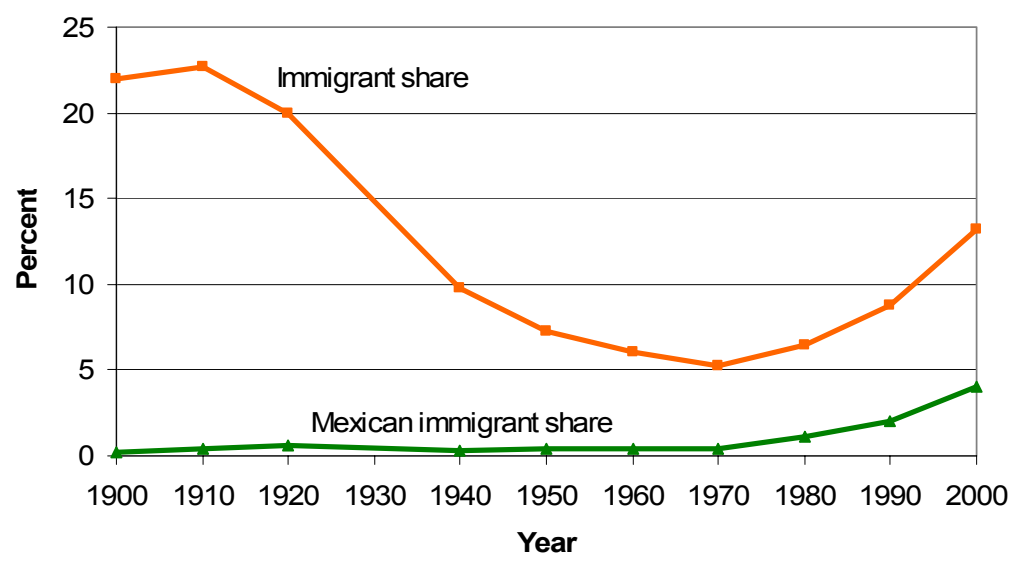

B. Male workers

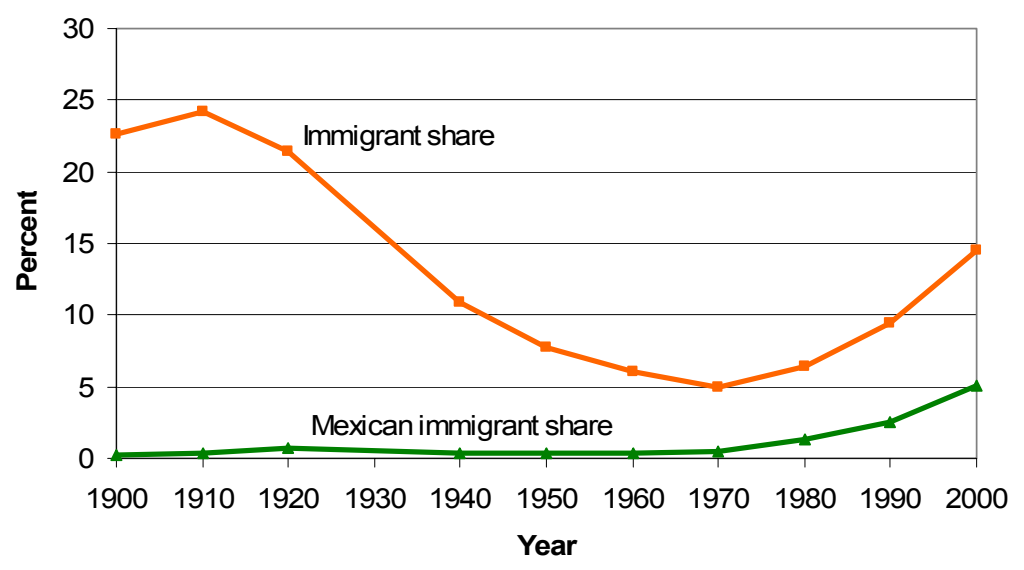

C. Female workers

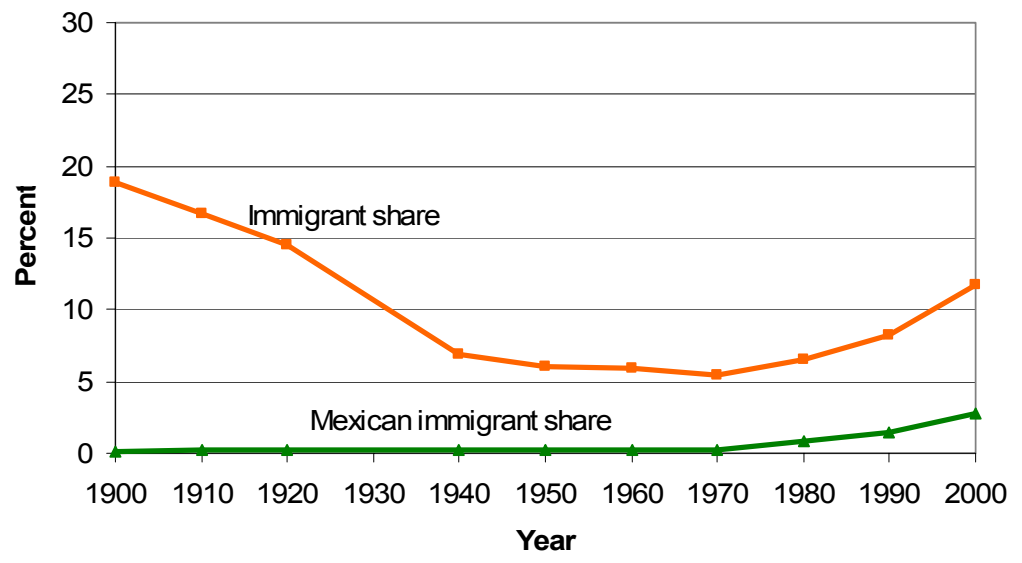

Notes: All statistics are calculated using the sample of workers aged 18-64. 
Figure 2. Mexican Immigrants as a Share of U.S. Immigrant Work-Force

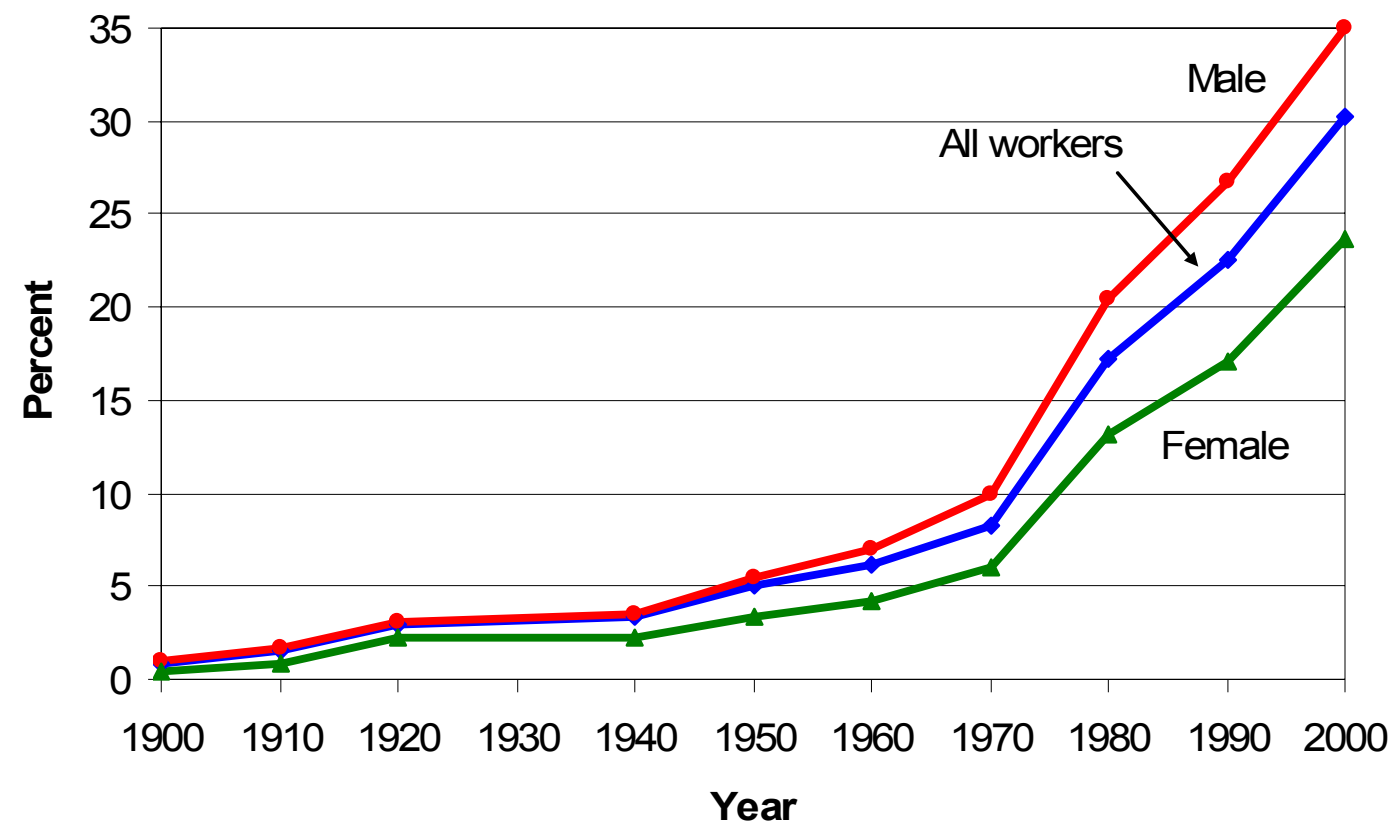

Notes: All statistics are calculated using the sample of workers aged 18-64. 
Figure 3. Wage growth of non-Mexican immigrant cohorts over time, relative to natives

Relative wage of immigrants who arrived when they were 25-34 years old

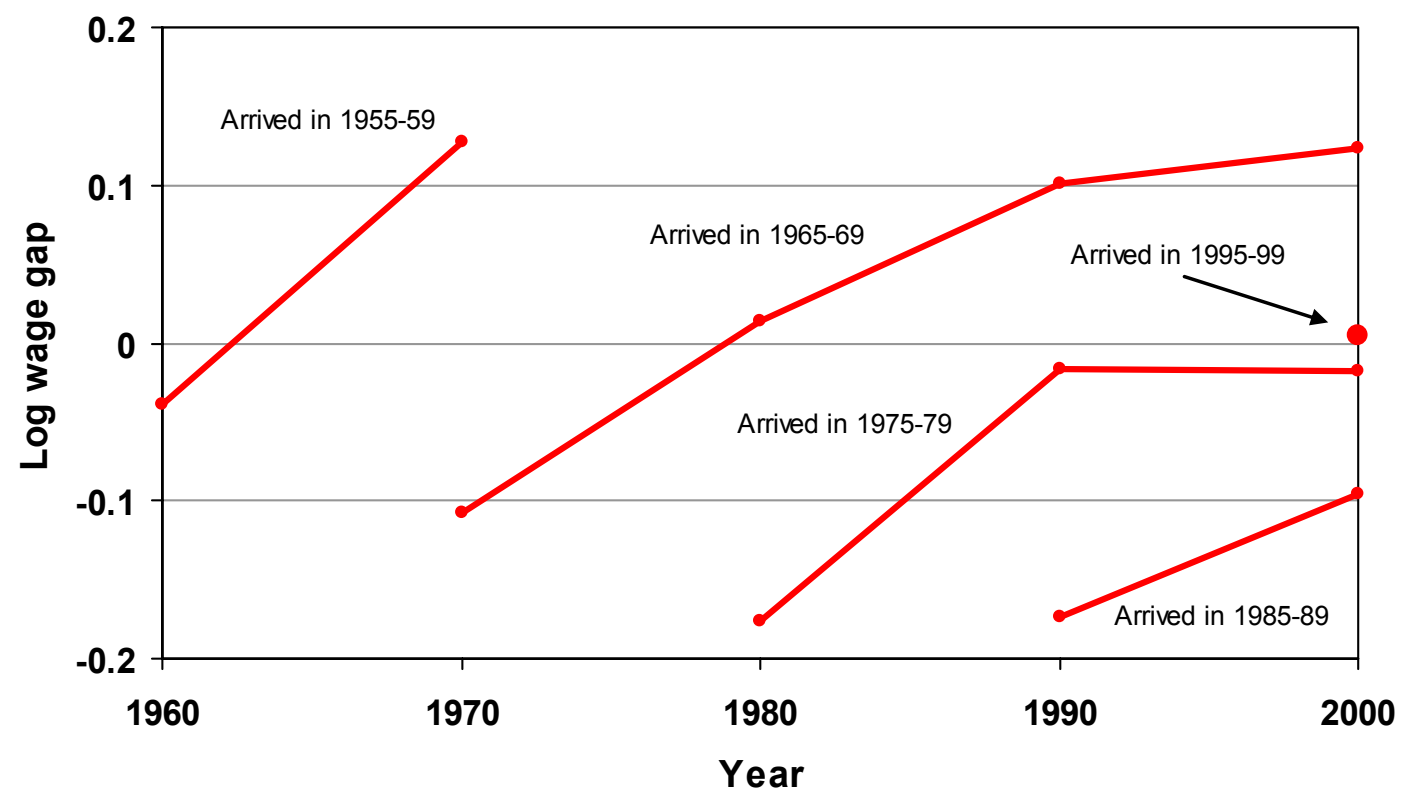


Figure 4. Wage growth of Mexican immigrant cohorts over time, relative to natives

Relative wage of immigrants who arrived when they were 25-34 years old

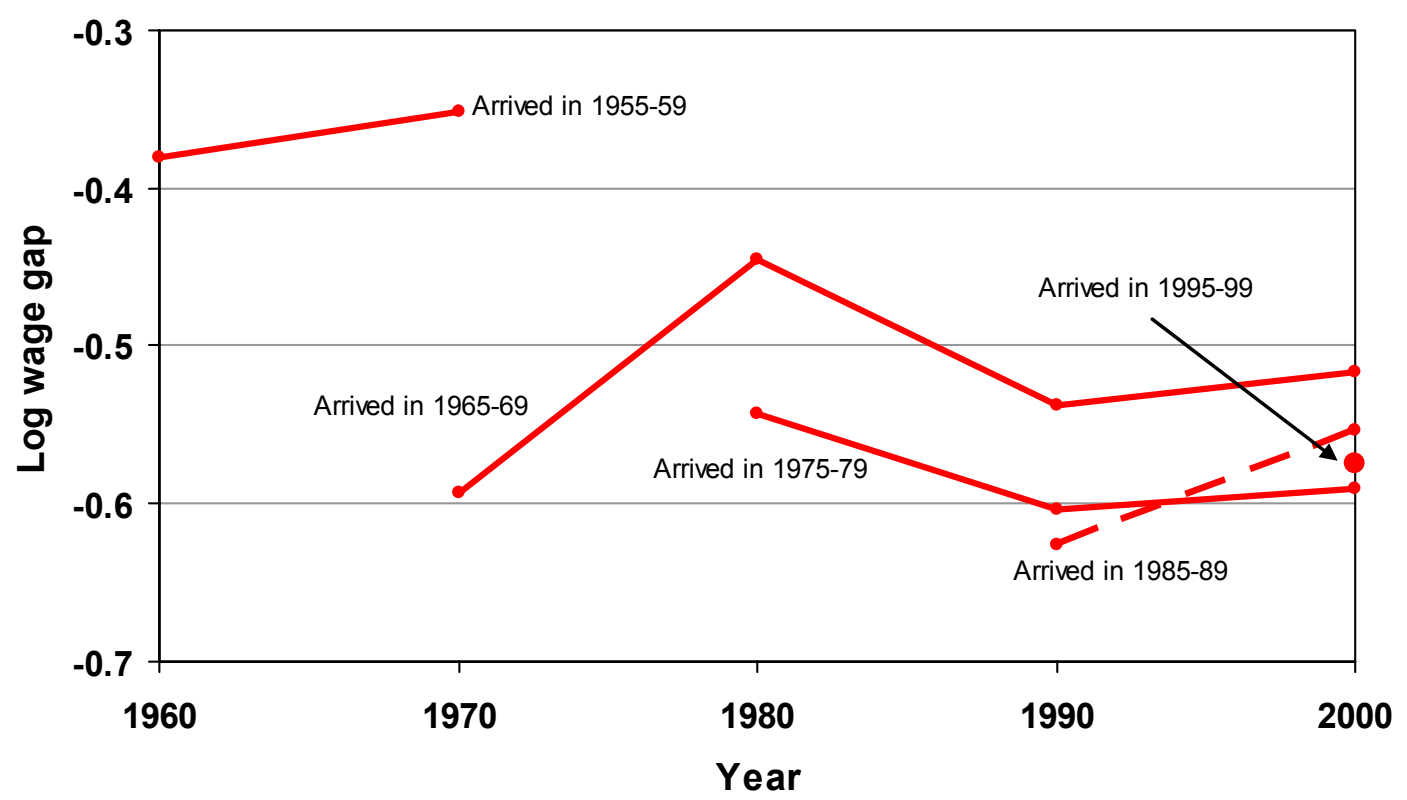


Figure 5. Wage growth of Mexican immigrant cohorts over time, relative to Mexican natives

Relative wage of immigrants who arrived when they were 25-34 years old

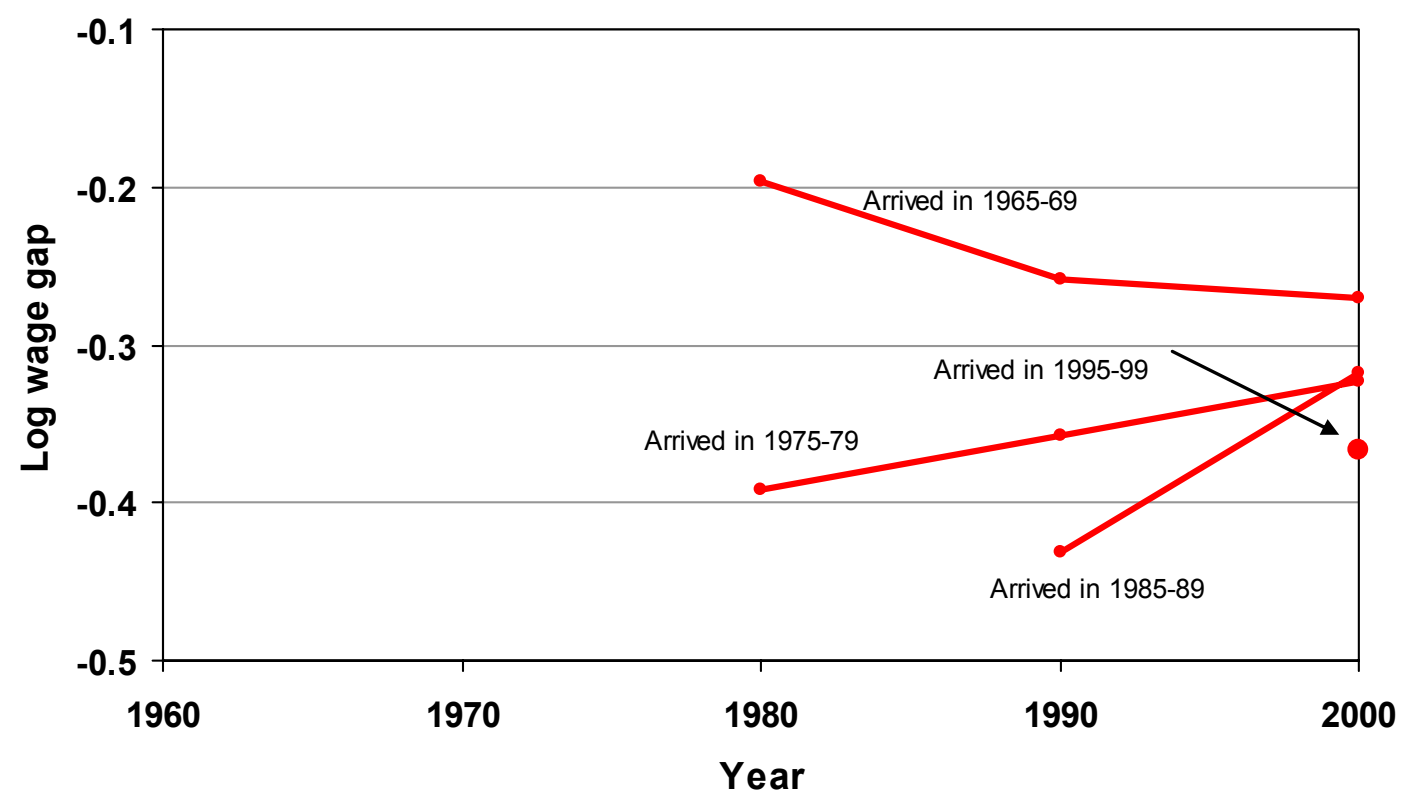


Figure 6. Wage growth of Mexican immigrant cohorts over time, relative to native worker, restricted to sample of high school dropouts

Relative wage of immigrants who arrived when they were 25-34 years old

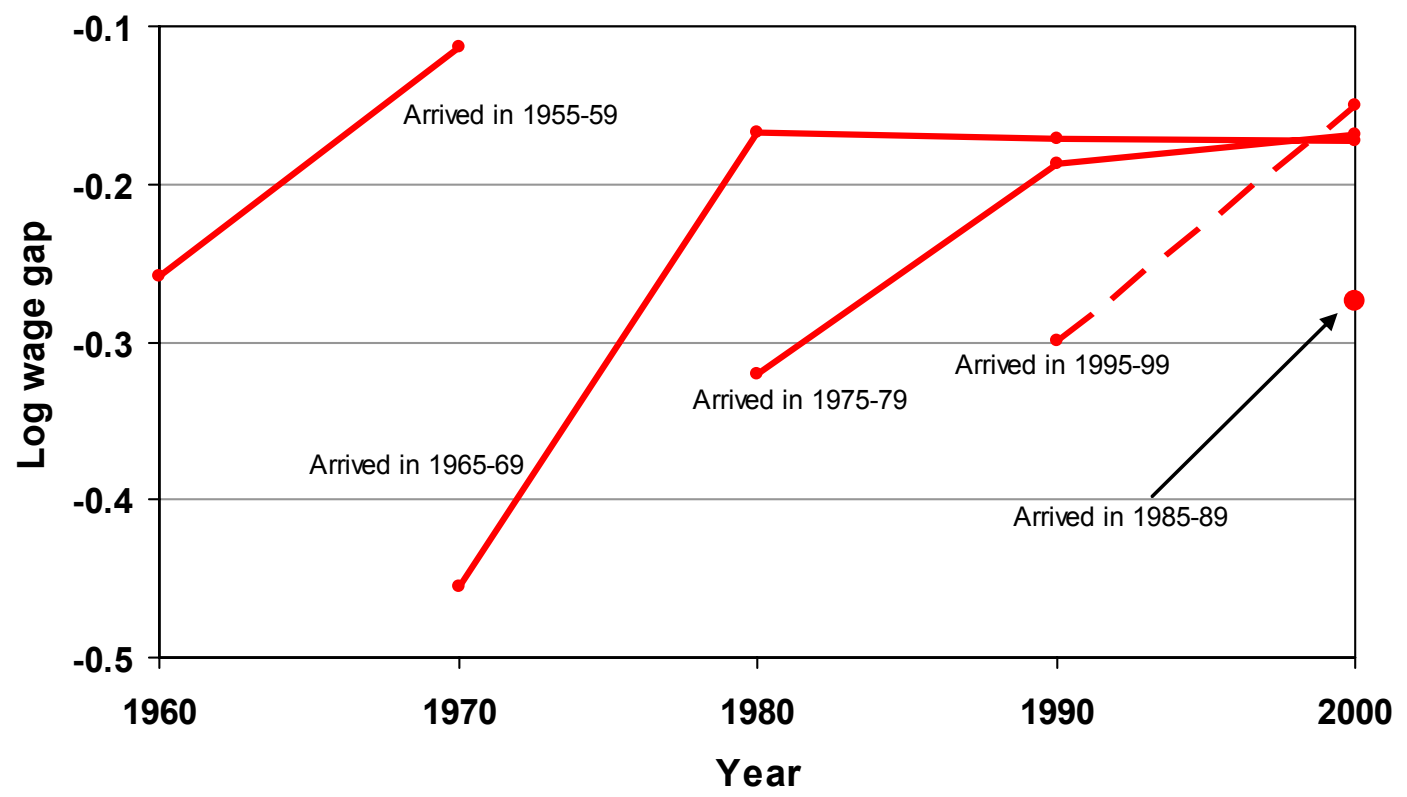

Notes: The samples of Mexican immigrants and native workers are restricted to male workers who are high school dropouts. 
Table 1. Regional concentration of the Mexican-born workforce, selected states

\begin{tabular}{|c|c|c|c|c|c|c|c|c|c|c|}
\hline \multirow{2}{*}{\multicolumn{11}{|c|}{$\underline{\text { Percent of Mexican immigrants residing in: }} \underline{1900} \underline{1910}$}} \\
\hline & & & & & & & & & & \\
\hline Arizona & 17.2 & 10.7 & 12.5 & 7.6 & 5.4 & 4.1 & 4.0 & 3.0 & 3.3 & 4.4 \\
\hline California & 7.8 & 19.9 & 17.9 & 40.4 & 40.3 & 44.6 & 55.1 & 58.7 & 57.4 & 42.1 \\
\hline Colorado & 0.0 & 1.3 & 3.1 & 1.9 & 1.0 & 0.9 & 0.4 & 0.8 & 0.8 & 2.0 \\
\hline Florida & 0.0 & 0.2 & 0.1 & 0.0 & 0.0 & 0.2 & 0.4 & 0.5 & 1.4 & 2.2 \\
\hline Georgia & 0.0 & 0.0 & 0.1 & 0.0 & 0.0 & 0.1 & 0.0 & 0.1 & 0.5 & 2.2 \\
\hline Illinois & 1.6 & 0.2 & 1.4 & 3.0 & 2.5 & 6.6 & 8.2 & 8.6 & 7.3 & 7.3 \\
\hline Kansas & 0.0 & 12.2 & 2.9 & 2.2 & 1.5 & 0.7 & 0.3 & 0.3 & 0.4 & 0.7 \\
\hline New Jersey & 0.0 & 0.0 & 0.0 & 0.0 & 0.2 & 0.0 & 0.3 & 0.1 & 0.3 & 0.8 \\
\hline New Mexico & 10.9 & 5.3 & 4.2 & 2.8 & 1.7 & 1.4 & 1.0 & 1.0 & 1.1 & 1.1 \\
\hline New York & 0.0 & 0.7 & 0.6 & 1.5 & 0.7 & 1.7 & 0.5 & 0.5 & 1.1 & 1.7 \\
\hline North Carolina & 0.0 & 0.0 & 0.0 & 0.0 & 0.0 & 0.1 & 0.0 & 0.1 & 0.2 & 2.0 \\
\hline Texas & 62.5 & 46.2 & 50.6 & 35.3 & 39.1 & 33.2 & 23.4 & 21.2 & 20.0 & 19.9 \\
\hline \multicolumn{11}{|c|}{ Mexican immigrants as percent of state's workforce: } \\
\hline Arizona & 19.3 & 17.1 & 23.6 & 7.8 & 4.3 & 2.3 & 2.2 & 2.9 & 4.8 & 10.2 \\
\hline California & 0.7 & 2.3 & 2.9 & 2.2 & 2.0 & 1.8 & 2.4 & 6.2 & 9.8 & 14.8 \\
\hline Colorado & 0.0 & 0.5 & 2.0 & 0.9 & 0.4 & 0.4 & 0.2 & 0.6 & 1.1 & 4.8 \\
\hline Florida & 0.0 & 0.1 & 0.1 & 0.0 & 0.0 & 0.0 & 0.1 & 0.1 & 0.5 & 1.6 \\
\hline Georgia & 0.0 & 0.0 & 0.0 & 0.0 & 0.0 & 0.0 & 0.0 & 0.0 & 0.4 & 2.8 \\
\hline Illinois & 0.1 & 0.0 & 0.1 & 0.1 & 0.1 & 0.4 & 0.6 & 1.8 & 3.1 & 6.5 \\
\hline Kansas & 0.0 & 2.7 & 1.2 & 0.7 & 0.5 & 0.2 & 0.1 & 0.3 & 0.7 & 2.9 \\
\hline New Jersey & 0.0 & 0.0 & 0.0 & 0.0 & 0.0 & 0.0 & 0.0 & 0.0 & 0.2 & 1.0 \\
\hline New Mexico & 10.6 & 6.0 & 8.6 & 3.2 & 1.8 & 1.2 & 1.0 & 2.1 & 4.0 & 7.3 \\
\hline New York & 0.0 & 0.0 & 0.0 & 0.0 & 0.0 & 0.1 & 0.0 & 0.1 & 0.3 & 1.1 \\
\hline North Carolina & 0.0 & 0.0 & 0.0 & 0.0 & 0.0 & 0.0 & 0.0 & 0.0 & 0.2 & 2.6 \\
\hline Texas & 3.4 & 4.3 & 7.7 & 3.1 & 3.0 & 2.4 & 1.9 & 3.7 & 6.0 & 10.9 \\
\hline
\end{tabular}

Notes: All statistics are calculated using the sample of workers aged 18-64. 
Table 2. Percent distribution of educational attainment

\begin{tabular}{|c|c|c|c|c|c|c|c|}
\hline & $\underline{1940}$ & $\underline{1950}$ & $\underline{1960}$ & $\underline{1970}$ & $\underline{1980}$ & $\underline{1990}$ & 2000 \\
\hline \multicolumn{8}{|l|}{ Male workers } \\
\hline \multicolumn{8}{|l|}{ Native-born } \\
\hline High school dropouts & $67.3 \%$ & $61.3 \%$ & $52.0 \%$ & $38.4 \%$ & $23.8 \%$ & $12.9 \%$ & $8.7 \%$ \\
\hline High school graduates & 20.0 & 24.2 & 27.8 & 35.2 & 39.1 & 36 & 34.5 \\
\hline Some college & 6.4 & 7.4 & 9.4 & 11.9 & 16.8 & 26.6 & 29.4 \\
\hline College graduates & 6.3 & 7.1 & 10.8 & 14.5 & 20.3 & 24.5 & 27.4 \\
\hline \multicolumn{8}{|l|}{ Mexican immigrants } \\
\hline High school dropouts & 94.6 & 91.2 & 88.3 & 82.6 & 77.2 & 70.4 & 63.0 \\
\hline High school graduates & 3.0 & 6.7 & 6.7 & 11.7 & 14.3 & 19.0 & 25.1 \\
\hline Some college & 1.0 & 1.5 & 2.7 & 3.6 & 5.7 & 7.8 & 8.5 \\
\hline College graduates & 1.4 & 0.6 & 2.4 & 2.2 & 2.9 & 2.8 & 3.4 \\
\hline \multicolumn{8}{|l|}{ Non-Mexican immigrants } \\
\hline High school dropouts & 84.4 & 76.4 & 64.5 & 45.5 & 30.2 & 21.0 & 17.0 \\
\hline High school graduates & 9.2 & 14.5 & 16.8 & 23.9 & 26.7 & 26.0 & 25.8 \\
\hline Some college & 2.8 & 4.0 & 8.3 & 11.7 & 15.2 & 21.3 & 20.9 \\
\hline College graduates & 3.7 & 5.1 & 10.4 & 18.9 & 27.9 & 31.7 & 36.3 \\
\hline \multicolumn{8}{|l|}{ Female workers } \\
\hline \multicolumn{8}{|l|}{ Native-born } \\
\hline High school dropouts & 50.6 & 46.3 & 42.4 & 31.2 & 19.2 & 9.8 & 6.5 \\
\hline High school graduates & 32.1 & 35.3 & 37.6 & 45.3 & 47.3 & 38.7 & 32.8 \\
\hline Some college & 9.5 & 10.1 & 11.0 & 12.6 & 17.9 & 29.9 & 33.5 \\
\hline College graduates & 7.8 & 8.3 & 9.0 & 11 & 15.6 & 21.6 & 27.3 \\
\hline \multicolumn{8}{|l|}{ Mexican immigrants } \\
\hline High school dropouts & 84.5 & 82.4 & 83.9 & 77.3 & 72.9 & 64.7 & 57.0 \\
\hline High school graduates & 12.5 & 10.3 & 11.4 & 16.9 & 17.7 & 21.9 & 26.6 \\
\hline Some college & 2.1 & 4.4 & 2.7 & 4.5 & 7.0 & 10.5 & 11.8 \\
\hline College graduates & 0.9 & 2.9 & 2 & 1.4 & 2.4 & 3.0 & 4.5 \\
\hline \multicolumn{8}{|l|}{ Non-Mexican immigrants } \\
\hline High school dropouts & 79.2 & 68.5 & 59.3 & 43.9 & 30.1 & 20.0 & 15.5 \\
\hline High school graduates & 15.8 & 22.3 & 25.5 & 33.7 & 35.2 & 31.1 & 27.6 \\
\hline Some college & 2.8 & 5.0 & 9.6 & 12.6 & 16.8 & 24.0 & 24.4 \\
\hline College graduates & 2.2 & 4.2 & 5.7 & 9.9 & 17.9 & 24.9 & 32.6 \\
\hline
\end{tabular}

Notes: All statistics are calculated using the sample of workers aged 18-64. 
Table 3. Percent of Mexican immigrants employed in "Top 10" occupations (occupations ranked according to their 2000 share of employment of Mexican immigrants)

\begin{tabular}{|c|c|c|c|c|c|c|c|c|c|c|}
\hline \multirow{2}{*}{\multicolumn{11}{|c|}{$\begin{array}{l}\frac{\text { Occupation }}{(1950 \text { coding })} \\
\text { Male workers }\end{array}$}} \\
\hline & & & & & & & & & & \\
\hline $\begin{array}{l}\text { Operatives, nec } \\
(690)\end{array}$ & 0.0 & 1.0 & 1.7 & 7.2 & 10.8 & 10.6 & 18.2 & 20.1 & 16.0 & 15.5 \\
\hline $\begin{array}{l}\text { Laborers, nec } \\
(970)\end{array}$ & 43.3 & 44.4 & 42.8 & 24.9 & 22.6 & 17.1 & 11.1 & 11.7 & 11.9 & 11.7 \\
\hline $\begin{array}{l}\text { Farm Laborers } \\
(820)\end{array}$ & 15.0 & 26.4 & 21.1 & 32.2 & 24.3 & 17.7 & 14.9 & 10.5 & 9.5 & 6.3 \\
\hline Gardeners (930) & 0.0 & 0.0 & 0.0 & 1.2 & 0.6 & 1.5 & 2.9 & 2.6 & 4.8 & 5.8 \\
\hline Cooks (754) & 0.0 & 0.0 & 0.2 & 1.3 & 0.9 & 1.4 & 1.7 & 3.3 & 4.9 & 5.4 \\
\hline $\begin{array}{l}\text { Truck Drivers } \\
(683)\end{array}$ & 0.0 & 2.2 & 0.2 & 1.9 & 3.5 & 4.4 & 2.8 & 2.2 & 3.5 & 4.2 \\
\hline $\begin{array}{l}\text { Managers, } \\
\text { Proprietors nec }\end{array}$ & & 14 & 15 & 16 & 1.2 & 3.1 & 2.2 & & & \\
\hline $\begin{array}{l}(290) \\
\text { Carpenters (510) }\end{array}$ & $\begin{array}{l}1.7 \\
0.0\end{array}$ & $\begin{array}{l}1.4 \\
1.2\end{array}$ & $\begin{array}{l}1.3 \\
1.4\end{array}$ & $\begin{array}{l}1.0 \\
1.3\end{array}$ & $\begin{array}{l}1.2 \\
1.5\end{array}$ & $\begin{array}{l}5.1 \\
1.5\end{array}$ & $\begin{array}{l}2.2 \\
1.8\end{array}$ & $\begin{array}{l}3.4 \\
2.3\end{array}$ & $\begin{array}{l}3.9 \\
2.5\end{array}$ & $\begin{array}{l}3.9 \\
3.6\end{array}$ \\
\hline Janitors (770) & 0.0 & 0.0 & 0.2 & 1.0 & 1.2 & 1.8 & 3.4 & 4.0 & 4.4 & 3.5 \\
\hline $\begin{array}{l}\text { Foremen, nec } \\
(523)\end{array}$ & 0.0 & 0.0 & 0.4 & 0.7 & 1.5 & 1.4 & 1.6 & 2.4 & 1.9 & 3.2 \\
\hline Female workers & & & & & & & & & & \\
\hline $\begin{array}{l}\text { Operatives, nec } \\
(690)\end{array}$ & 0.0 & 5.0 & 10.1 & 31.5 & 30.9 & 29.8 & 34.9 & 35.8 & 26.9 & 21.2 \\
\hline $\begin{array}{l}\text { Private } \\
\text { household ( } 720)\end{array}$ & 50.0 & 25.0 & 16.0 & 14.7 & 10.3 & 13.6 & 5.4 & 2.8 & 4.2 & 9.0 \\
\hline $\begin{array}{l}\text { Clerical workers } \\
(390)\end{array}$ & 0.0 & 0.0 & 0.8 & 1.8 & 2.9 & 3.2 & 2.8 & 5.1 & 5.4 & 7.6 \\
\hline $\begin{array}{l}\text { Farm Laborers } \\
(820)\end{array}$ & 0.0 & 30.0 & 13.9 & 5.6 & 2.9 & 4.7 & 7.4 & 8.7 & 7.7 & 5.0 \\
\hline Cooks (754) & 0.0 & 0.0 & 1.3 & 0.9 & 1.5 & 2.7 & 1.8 & 2.4 & 3.7 & 4.9 \\
\hline Janitors (770) & 0.0 & 0.0 & 0.0 & 0.7 & 0.0 & 0.5 & 0.9 & 2.7 & 5.0 & 4.5 \\
\hline $\begin{array}{l}\text { Service, except } \\
\text { private } \\
\text { household, nec }\end{array}$ & & & & & & & & & & \\
\hline (790) & 25.0 & 0.0 & 1.3 & 1.8 & 2.9 & 4.0 & 4.3 & 1.9 & 2.3 & 4.3 \\
\hline Cashiers (320) & 0.0 & 0.0 & 0.0 & 0.0 & 1.5 & 0.5 & 2.0 & 2.1 & 3.3 & 3.7 \\
\hline $\begin{array}{l}\text { Managers, } \\
\text { officials, } \\
\text { proprietors, nec }\end{array}$ & 0.0 & 0.0 & 3.8 & 0.0 & 4.4 & 2.0 & 1.2 & 1.7 & 2.7 & 3.3 \\
\hline $\begin{array}{l}\text { Attendants, nec } \\
\text { (731) }\end{array}$ & 0.0 & 0.0 & 0.0 & 0.0 & 0.0 & 0.2 & 0.1 & 1.7 & 2.1 & 2.9 \\
\hline
\end{tabular}

Notes: All statistics are calculated using the sample of workers aged 18-64. 


\section{Table 4. Trends in immigrant wages relative to native-born workers}

Male workers

A. Unadjusted wage gap

Mexican immigrants

Non-Mexican immigrants

B, Adjusted wage gap, adjusts for education, age

Mexican immigrants

Non-Mexican immigrants

C. Adjusted wage gap, adjusts for education, age, state of residence Mexican immigrants

Non-Mexican immigrants

Female workers

D. Unadjusted wage gap

Mexican immigrants

Non-Mexican immigrants

E. Adjusted wage gap, adjusts for education, age

Mexican immigrants

Non-Mexican immigrants

F. Adjusted wage gap, adjusts for education, age, state of residence Mexican immigrants

Non-Mexican immigrants

$\begin{array}{lllllll}\underline{1940} & \underline{1950} & \underline{1960} & \underline{1970} & \underline{1980} & \underline{1990} & \underline{2000} \\ -.475 & -.385 & -.365 & -.390 & -.408 & -.544 & -.533 \\ (.022) & (.030) & (.016) & (.014) & (.004) & (.003) & (.002) \\ .175 & .131 & .104 & .072 & -.022 & -.004 & -.034 \\ (.005) & (.007) & (.005) & (.005) & (.002) & (.002) & (.002)\end{array}$

$\begin{array}{lllllll}-.453 & -.352 & -.249 & -.205 & -.148 & -.149 & -.144 \\ (.020 & (.028) & (.015) & (.013) & (.003) & (.003) & (.002) \\ .092 & .093 & .102 & .035 & -.048 & -.042 & -.073 \\ (.004) & (.007) & (.004) & (.004) & (.002) & (.002) & (.001)\end{array}$

$\begin{array}{lccllll}-.444 & -.377 & -.304 & -.255 & -.202 & -.208 & -.176 \\ (.019) & (.027) & (.014) & (.013) & (.003) & (.003) & (.002) \\ -.016 & .019 & .016 & -.027 & -.062 & -.104 & -.106 \\ (.004) & (.007) & (.004) & (.004) & (.002) & (.002) & (.001)\end{array}$

$\begin{array}{lcccccc}-.329 & -.193 & -.335 & -.217 & -.135 & -.316 & -.401 \\ (.056) & (.068) & (.033) & (.025) & (.005) & (.004) & (.003) \\ .026 & .065 & .052 & .057 & .060 & .081 & .036 \\ (.009) & (.013) & (.007) & (.006) & (.002) & (.002) & (.002)\end{array}$

$\begin{array}{lllllll}-.247 & -.104 & -.177 & -.049 & .035 & -.015 & -.074 \\ (.051) & (.064) & (.031) & (.023) & (.005) & (.004) & (.003) \\ .080 & .123 & .100 & .078 & .045 & .072 & .025 \\ (.008) & (.013) & (.007) & (.006) & (.002) & (.002) & (.002)\end{array}$

$\begin{array}{lllllll}-.246 & -.132 & -.230 & -.094 & -.038 & -.120 & -.137 \\ (.050) & (.062) & (.031) & (.023) & (.005) & (.004) & (.003) \\ -.013 & .021 & -.001 & .010 & .011 & -.017 & -.035 \\ (.008) & (.012) & (.007) & (.006) & (.002) & (.002) & (.002)\end{array}$

Notes: Standard errors are reported in parentheses. The numbers of observations in the male regressions are as follows: 208,729 in the 1940 Census, 79,824 in the 1950 Census, 362,823 in the 1960 Census, 393,653 in the 1970 Census, 2,546,859 in the 1980 Census, 2,809,917 in the 1990 Census, and 3,164,510 in the 2000 Census. The numbers of observations in the female regressions are: 74,101 in the 1940 Census, 33,777 in the 1950 Census, 163,027 in the 1960 Census, 227,736 in the 1970 Census, 1,961,549 in the 1980 Census, 2,405,910 in the 1990 Census, and 2,800,811 in the 2000 Census. The reported coefficients are log wage gaps relative to native-born workers. 


\section{Table 5. Trends in the relative wage of newly arrived immigrants}

Male workers

$\begin{array}{lllllll}\underline{1940} & \underline{1950} & \underline{1960} & \underline{1970} & \underline{1980} & \underline{1990} & \underline{2000} \\ & & & & & & \\ -.342 & --- & -.526 & -.593 & -.647 & -.812 & -.764 \\ (.258) & --- & (.044) & (.031) & (.007) & (.006) & (.004) \\ .101 & --- & -.074 & -.160 & -.218 & -.289 & -.203 \\ (.042) & --- & (.014) & (.011) & (0.004) & (0.004) & (.003)\end{array}$

B. Adjusted wage gap, adjusts for education, age

Mexican immigrants

$\begin{array}{lllllll}-.408 & --- & -.316 & -.254 & -.214 & -.201 & -.164 \\ (.230) & --- & (.039) & (.028) & (.006) & (.005) & (.004) \\ -.004 & --- & -.077 & -.177 & -.210 & -.200 & -.149 \\ (.037) & --- & (.013) & (.010) & (.004) & (.003) & (.003)\end{array}$

Non-Mexican immigrants

C. Adjusted wage gap, adjusts for education, age, state of residence Mexican immigrants

Non-Mexican immigrants

$\begin{array}{lllllll}-.459 & --- & -.396 & -.325 & -.272 & -.277 & -.187 \\ (.219) & & (.038) & (.027) & (.006) & (.005) & (.004) \\ -.111 & --- & -.166 & -.238 & -.230 & -.272 & -.180 \\ (.035) & & (.012) & (.010) & (.004) & (.003) & (.003)\end{array}$

Female workers

D. Unadjusted wage gap

Mexican immigrants

Non-Mexican immigrants

$\begin{array}{lllllll}--- & --- & -.557 & -.286 & -.248 & -.503 & -.544 \\ & & (.084) & (.056) & (.011) & (.010) & (.007) \\ -.125 & --- & -.046 & .018 & -.040 & -.137 & -.150 \\ (.053) & & (.019) & (.014) & (.005) & (.005) & (.004)\end{array}$

E. Adjusted wage gap, adjusts for education, age

Mexican immigrants

Non-Mexican immigrants

$\begin{array}{lccclll}-- & --- & -.334 & -.072 & .001 & -.092 & -.096 \\ & & (.079) & (.053) & (.011) & (.009) & (.006) \\ -.004 & --- & .018 & .054 & -.025 & -.078 & -.100 \\ (.048) & & (.018) & (.013) & (.005) & (.004) & (.004)\end{array}$

F. Adjusted wage gap, adjusts for education, age, state of residence Mexican immigrants

Non-Mexican immigrants

$\begin{array}{lllllll}--- & --- & -.395 & -.133 & -.078 & -.214 & -.144 \\ & & (.077) & (.052) & (.011) & (.009) & (.006) \\ -.119 & --- & -.086 & -.022 & -.066 & -.181 & -.155 \\ (.046) & & (.017) & (.013) & (.005) & (.004) & (.004)\end{array}$

Notes: Standard errors are reported in parentheses. A newly arrived immigrant has been in the United States five years or less as of the time of the Census. The numbers of observations in the male regressions are as follows: 186,314 in the 1940 Census, 343,028 in the 1960 Census, 377,656 in the 1970 Census, 2,416,854 in the 1980 Census, 2,612,394 in the 1990 Census, and 2,820,033 in the 2000 Census. The numbers of observations in the female regressions are as follows: 69,147 in the 1940 Census, 154,868 in the 1960 Census, 217,844 in the 1970 Census, $1,856,973$ in the 1980 Census, 2,250,119 in the 1990 Census, and 2,541,595 in the 2000 Census. The reported wage coefficients are log wage gaps relative to native-born workers. 


\section{Table 6. Placement of median immigrant in native wage distribution}

\begin{tabular}{|c|c|c|c|c|c|c|c|c|c|c|}
\hline \multirow{3}{*}{$\begin{array}{l}\text { Group: } \\
\text { Male, unadjusted } \\
\text { placement }\end{array}$} & \multicolumn{5}{|c|}{$\begin{array}{c}\text { Percentile placement of median } \\
\text { Mexican immigrant }\end{array}$} & \multicolumn{5}{|c|}{$\begin{array}{l}\text { Percentile placement of median } \\
\text { non-Mexican immigrant }\end{array}$} \\
\hline & $\underline{1960}$ & $\underline{1970}$ & $\underline{1980}$ & $\underline{1990}$ & $\underline{2000}$ & $\underline{1960}$ & $\underline{1970}$ & $\underline{1980}$ & $\underline{1990}$ & $\underline{2000}$ \\
\hline & & & & & & & & & & \\
\hline All immigrant & 26.2 & 22.0 & 23.6 & 19.7 & 19.0 & 53.6 & 53.4 & 47.7 & 47.8 & 45.5 \\
\hline Recent immigrants & 17.0 & 14.7 & 14.1 & 12.4 & 12.3 & 40.5 & 34.2 & 30.3 & 27.7 & 32.8 \\
\hline $\begin{array}{l}\text { Male, adjusts for } \\
\text { differences in } \\
\text { education, age, state } \\
\text { of residence }\end{array}$ & & & & & & & & & & \\
\hline All immigrants & 26.7 & 27.1 & 33.4 & 34.9 & 37.8 & 49.6 & 46.7 & 43.6 & 41.2 & 41.9 \\
\hline Recent immigrants & 19.5 & 22.4 & 28.0 & 29.8 & 35.9 & 35.9 & 29.0 & 29.6 & 28.3 & 36.6 \\
\hline $\begin{array}{l}\text { Female, unadjusted } \\
\text { placement }\end{array}$ & & & & & & & & & & \\
\hline All immigrants & 27.5 & 33.5 & 38.1 & 30.6 & 25.9 & 50.7 & 52.1 & 52.4 & 52.3 & 49.7 \\
\hline Recent immigrants & 19.8 & 31.7 & 32.1 & 22.8 & 20.9 & 43.7 & 47.4 & 44.1 & 37.8 & 36.0 \\
\hline $\begin{array}{l}\text { Female, adjusts for } \\
\text { differences in } \\
\text { education, age, state } \\
\text { of residence }\end{array}$ & & & & & & & & & & \\
\hline All immigrants & 29.0 & 39.1 & 42.9 & 38.6 & 37.6 & 46.6 & 48.0 & 48.5 & 46.2 & 45.7 \\
\hline Recent immigrants & 21.7 & 36.5 & 40.3 & 32.4 & 36.4 & 41.6 & 42.8 & 41.1 & 34.1 & 36.0 \\
\hline
\end{tabular}

Notes: The statistics giving the "unadjusted placement" reported in this table give the fraction of the relevant native workforce that has a wage below that of the median of the Mexican or non-Mexican immigrant. The adjusted placement gives the fraction of the relevant native workforce that has a residual from a wage regression that lies below the median residual of the Mexican or non-Mexican immigrant, where the regression includes a vector of educational attainment fixed effects, a third-order polynomial in the worker's age, and a vector of fixed effects indicating the worker's state of residence. 
Table 7. Evolution of relative wage of non-Mexican immigrants over time (relative to native workers)

\begin{tabular}{|c|c|c|c|c|c|c|}
\hline Year of entry & Age at migration & 1960 & 1970 & 1980 & 1990 & 2000 \\
\hline $1955-1959$ & $25-34$ & -0.039 & 0.127 & --- & --- & --- \\
\hline $1955-1959$ & $35-44$ & -0.080 & 0.067 & --- & --- & --- \\
\hline 1955-1959 & $45-54$ & -0.122 & -0.005 & --- & --- & --- \\
\hline $1965-1969$ & $5-14$ & --- & --- & --- & 0.087 & 0.110 \\
\hline $1965-1969$ & $15-24$ & --- & -- & -0.019 & 0.062 & 0.037 \\
\hline $1965-1969$ & $25-34$ & --- & -0.107 & 0.014 & 0.101 & 0.124 \\
\hline $1965-1969$ & $35-44$ & --- & -0.182 & -0.138 & -0.017 & --- \\
\hline $1965-1969$ & $45-54$ & --- & -0.268 & -0.231 & --- & --- \\
\hline $1975-1979$ & $5-14$ & --- & --- & --- & --- & 0.107 \\
\hline $1975-1979$ & $15-24$ & --- & --- & --- & 0.054 & 0.055 \\
\hline $1975-1979$ & $25-34$ & --- & --- & -0.176 & -0.017 & -0.018 \\
\hline $1975-1979$ & $35-44$ & --- & --- & -0.203 & -0.130 & -0.065 \\
\hline $1975-1979$ & $45-54$ & --- & --- & -0.291 & -0.178 & --- \\
\hline 1985-1989 & $15-24$ & --- & --- & --- & --- & -0.043 \\
\hline 1985-1989 & $25-34$ & --- & --- & --- & -0.174 & -0.096 \\
\hline 1985-1989 & $35-44$ & --- & --- & --- & -0.262 & -0.262 \\
\hline 1985-1989 & $45-54$ & --- & --- & --- & -0.345 & -0.354 \\
\hline 1995-1999 & $25-34$ & --- & --- & --- & --- & 0.004 \\
\hline
\end{tabular}

Note: The "age at migration" reflects the age of the workers at the time of the Census immediately following the arrival of the immigrant cohort. 
Table 8. Evolution of relative wage of Mexican immigrants over time (relative to native workers)

\begin{tabular}{|c|c|c|c|c|c|c|}
\hline Year of entry & Age at migration & $\underline{1960}$ & $\underline{1970}$ & $\underline{1980}$ & 1990 & 2000 \\
\hline $1955-1959$ & $25-34$ & -0.381 & -0.352 & --- & --- & --- \\
\hline $1955-1959$ & $35-44$ & -0.626 & -0.381 & --- & --- & --- \\
\hline 1955-1959 & $45-54$ & -0.835 & -0.660 & --- & --- & --- \\
\hline $1965-1969$ & $5-14$ & --- & --- & --- & -0.173 & -0.271 \\
\hline $1965-1969$ & $15-24$ & --- & --- & -0.231 & -0.360 & -0.440 \\
\hline $1965-1969$ & $25-34$ & --- & -0.593 & -0.445 & -0.537 & -0.517 \\
\hline 1965-1969 & $35-44$ & --- & -0.628 & -0.529 & -0.606 & --- \\
\hline 1965-1969 & $45-54$ & --- & -0.711 & -0.524 & --- & --- \\
\hline $1975-1979$ & $5-14$ & --- & --- & --- & --- & -0.261 \\
\hline 1975-1979 & $15-24$ & --- & --- & --- & -0.352 & -0.423 \\
\hline 1975-1979 & $25-34$ & --- & --- & -0.543 & -0.603 & -0.591 \\
\hline 1975-1979 & $35-44$ & --- & --- & -0.759 & -0.783 & -0.646 \\
\hline $1975-1979$ & $45-54$ & --- & --- & -0.816 & -0.753 & --- \\
\hline 1985-1989 & $15-24$ & --- & --- & --- & --- & -0.361 \\
\hline 1985-1989 & $25-34$ & --- & --- & --- & -0.626 & -0.554 \\
\hline 1985-1989 & $35-44$ & --- & --- & --- & -0.880 & -0.716 \\
\hline 1985-1989 & $45-54$ & --- & --- & --- & -1.029 & -0.732 \\
\hline 1995-1999 & $25-34$ & --- & --- & --- & --- & -0.574 \\
\hline
\end{tabular}

Note: The "age at migration" reflects the age of the workers at the time of the Census immediately following the arrival of the immigrant cohort. 
Table 9. Distribution of educational attainment for Mexican native-born workers

Male workers

$\underline{1980}$

$\underline{1990}$

$\underline{2000}$

Native-born of Mexican ancestry

High school dropouts

45.5

27.6

21.0

High school graduates

33.4

38.6

40.0

Some college

14.3

24.7

27.7

College graduates

6.7

9.1

11.3

All other native born workers

High school dropouts

23.3

12.5

8.3

High school graduates

39.3

35.9

34.3

Some college

16.8

26.7

29.5

College graduates

24.9

27.9

Mexican immigrants

High school dropouts

77.2

70.4

63.0

High school graduates

14.3

19.0

25.1

Some college

5.7

7.8

8.5

College graduates

2.8

3.4

Female workers

Native-born of Mexican ancestry

High school dropouts

39.6

23.0

16.5

High school graduates

42.0

41.1

38.4

Some college

13.4

27.2

32.1

College graduates

5.0

8.7

13.0

All other native born workers

High school dropouts

18.8

9.4

6.2

High school graduates

47.4

38.6

32.6

Some college

18.1

30.0

33.5

15.8

22.0

27.7

Mexican immigrants

High school dropouts

72.9

64.7

57.0

17.7

21.9

26.6

Some college

7.0

10.5

11.8

College graduates

2.4

3.0

4.5

Notes: All statistics are calculated using the sample of workers aged 18-64. 
Table 10. Trends in the relative wage of the Mexican-origin population

$\underline{\text { Male workers }}$

$\underline{1980}$

$\underline{1990}$

$\underline{2000}$

A. Relative weekly wage (relative to other natives)

Mexican immigrant

$\begin{array}{lll}-.414 & -.553 & -.543 \\ (.004) & (.003) & (.002) \\ .017 & -.004 & -.044 \\ (.002) & (.002) & (.002) \\ -.238 & -.298 & -.310 \\ (.003) & (.003) & (.003)\end{array}$

Other immigrant

Native-born of Mexican ancestry

(.003)

(.003)

$(.003)$

B. Adjusted relative weekly wage (adjusts for education, age)

Mexican immigrant

$\begin{array}{lll}-.151 & -.154 & -.148 \\ (.003) & (.003) & (.002) \\ -.049 & -.045 & -.076 \\ (.002) & (.002) & (.001) \\ -.075 & -.098 & -.075 \\ (.003) & (.002) & (.002)\end{array}$

Other immigrant

Native-born of Mexican ancestry

(.003)

$(.002)$

$(.002)$

$\underline{\text { Female workers }}$

C. Relative weekly wage (relative to other natives)

Mexican immigrant

Other immigrant

.058

$(.004)$

$(.002)$

.077

.032

$-.093$

(.002)

$(.002)$

Native-born of Mexican ancestry

(.003)

$-.134$

$-.150$

(.003)

(.003)

D. Adjusted relative weekly wage (adjusts for education, age)

$\begin{array}{lccc}\text { Mexican immigrant } & .036 & -.015 & -.073 \\ \text { Other immigrant } & (.005) & (.004) & (.003) \\ & .045 & .072 & .025 \\ \text { Native-born of Mexican ancestry } & (.002) & (.002) & (.002) \\ & .015 & .013 & .022 \\ & (.003) & (.003) & (.003)\end{array}$

Notes: Standard errors are reported in parentheses. The numbers of observations in the regressions are as follows: 2,546,859 in the 1980 Census, 2,809,917 in the 1990 Census, and 3,164,510 in the 2000 Census. The reported wage coefficients are log wage gaps relative to native-born workers of non-Mexican ancestry. 


\section{Table 11. Comparing the actual impact of the 1980-2000 immigrant influx with a counterfactual of no Mexican immigration during period (Predicted percent change in the weekly wage)}

Specification/Group: Short-run: Capital is fixed All workers

High school dropouts

High school graduates

Some college

College graduates

\section{Actual impact}

$-3.3 \%$

$-8.2 \%$

$-2.2$

$-2.6$

$-3.8$

\section{Counterfactual: No Mexican immigration}

$-2.2 \%$

$-0.1 \%$

$-1.2$

$-2.3$

$-3.9$

Long-run: Capital is perfectly

elastic

All workers

0.1

0.6

High school dropouts

$-4.8$

2.7

High school graduates

1.1

1.6

Some college

0.8

0.5

College graduates

$-0.5$

$-1.1$

Notes: The simulation models in equations (9) and (12) generate wage effects for specific education-experience cells. We used the size of the native-born workforce in 2000 in each of the cells to calculate the weighted aggregates reported in this table. The predicted percent changes refer to the product of the predicted log wage change times 100 . 